\title{
Reflexiones de San Agustín en Confesiones VIII.
}

\author{
Tolle lege (déjalo ya, lee) y Rom. 13,13
}

Reflections of saint augustine in Confessions VIII

Tolle lege (Stop it, read) and Rom.13,13

\author{
Dr. Manuel VILLEGAS RODRÍGUEZ \\ San Lorenzo de El Escorial \\ mvillegas35rodriguez54@gmail.com
}

\begin{abstract}
Resumen: San Agustín narra en el Libro VIII de Confesiones hechos y reflexiones que le conducen a su "conversión", entendida aquí como decisión por un exclusivo servicio a Dios. Le mueve la Causa Primordial, Dios, que le inspira visitar a Simpliciano en busca de asesoramiento, y a meditar sobre la providencial llegada de Ponticiano. Todo esto produce en Aurelio Agustín una profunda crisis emocional que termina en el jardín de su casa donde se refugia para sosegarse, acompañado siempre por Alipio. Allí escuchó una voz infantil que cantaba: "Déjalo ya, lee" y viene a leer Rom. 13,13. Todo esto él lo interpreta como un mandato celestial para abandonar sus dudas y sombras y experimenta una iluminación tal en su espíritu que asume la firme decisión de revestirse en Cristo. Alipio se aplica el versículo Rom. 4,1, y tiene también su especial conversión. En el año 385, en Milán, Aurelio Agustín tuvo que resolver un problema causado por su madre en relación a la fiesta de la Leticia. En el año 393 tras un profundo estudio suyo exegético sobre Rom 13,13, el novel sacerdote Agustín, decide abolir esa fiesta en Hipona. Ante la terca oposición de sus fieles, estuvo al borde de huir y abandonar la Diócesis. ¿Existe alguna conexión entre estos hechos?
\end{abstract}

\footnotetext{
Abstract: Saint Augustine narrates in Book VIII of Confessions facts and reflections that lead him to his "conversion", understood here as a decision for an exclusive service to God. He is moved by the Primordial Cause, God, who inspires him to visit Simpliciano for advice, and to meditate on the providential arrival of Ponticiano. All this produces in Aurelio Agustín a deep emotional crisis that ends in the garden of his house where he takes refuge to calm down, always accompanied by Alipio. There he heard a childish voice singing: "Stop it, read" and come to read Rom. 13.13. All this he interprets as a
} 
heavenly command to abandon his doubts and shadows and experiences such illumination in his spirit that he makes the firm decision to put on Christ. Alypius applies the verse Rom. 4.1, and it also has its special conversion. In the year 385, in Milan, Aurelio Agustín had to solve a problem caused by his mother in relation to the Leticia party. In the year 393, after a profound exegetical study of his on Rom 13:13, the new priest Augustine decided to abolish this festival in Hippo. Faced with the stubborn opposition of his faithful, he was on the verge of fleeing and leaving the Diocese. Is there a connection between these events?

Palabras Clave: Obras de san Agustín, especialmente Confesiones, sus cartas y libros anteriores al año 401 .

Keywords: Works of Saint Augustine, especially Confessions, his letters and books prior to the year 401 .

\section{Sumario:}

\section{Introducción.}

II. Reflexiones de san Agustín.

2.1. Reflexión 1 ${ }^{a}$ : La misericordia de Dios (Conf. VIII.1,1).

2.2. Reflexión 2a: La consulta a Simpliciano (Conf. VIII.1,1-5,12).

2.3. Reflexión $3^{a}$ : La visita de Ponticiano (Conf. VIII.6, 13-7,18).

2.4. Reflexión 4a: La indecisión de Agustín (Conf. VIII.8,20-11,27).

2.5. La luz en el jardin de Milán: (Conf. VIII.12,28-30).

2.6. La conversión de Alipio.

\section{Dos temas a dilucidar.}

3.1. Romanos 13,13. MILÁN, año 386.

3.1.1. Santa Mónica en Milán, año 385.

3.1.2. La fiesta de la Leticia. Hipona, año 393.

3.2. Tolle, lege.

3.2.1. El significado de Tolle.

\section{Bibliografía.}

Recibido: octubre 2021.

Aceptado: diciembre 2021. 


\section{INTRODUCCIÓN}

Para escribir sobre san Agustín es conveniente no amedrentarse por la cantidad de escritos que se han dedicado a su persona y a su obra. Rafael Lazcano en su magnífico trabajo recoge 81 publicaciones bibliográficas que tratan de ordenar los títulos sobre temas agustinianos, y 36 páginas de internet ${ }^{1}$. Además, y es su obra por ello admirable, enumera 6390 publicaciones, lógicamente, de diverso contenido e interés, en lengua española editadas entre el año 1502 y el $2006^{2}$. Añádanse las bibliografías en otras lenguas; italiana, francesa, inglesa, alemana e incluyamos la japonesa ${ }^{3}$, y el asombro y la admiración te invade.

No obstante, dedico este análisis y comentario sobre temas del libro VIII de Confesiones a la llamada conversión de san Agustín. Se han editado ya muchas publicaciones ${ }^{4} \mathrm{y}$, sin embargo, el atreverse a presentar una nueva más, significa que por parte de este autor se estima que aún hay algún punto posiblemente obscuro. Hasta se aventura la posibilidad de proponer algo novedoso, cuya importancia no está en las manos propias, sino en el juicio ajeno.

Deseo, pues, exponer en este estudio mi personal interpretación sobre la conversión de san Agustín, según es narrada en el Libro VIII de Confesiones. Es una idea que me ha obsesionado -no de forma perturbadora sino de modo pacífico y tranquilo- durante años. Y con mayor o menor intensidad, según transcurría el tiempo he ido preparando material que me sirviera en el momento oportuno para poder exponer mis ideas de manera adecuada y de forma sosegada, porque en este mi momento histórico, no hay otra cuestión que me impida llevarla a cabo. Este artículo es un adelanto de uno posterior, que esperamos conseguir.

${ }^{1}$ LAZCANO, R., Bibliografia de san Agustín en lengua española (1502-2006), Guadarrama 207, pp.47-52.

${ }^{2}$ O.c., Ibi

${ }^{3}$ VILLEGAS RODRÍGUEZ, M., Akira Yamada; un agustinólogo japonés, en LEA 86 (eneromarzo 2007) 27-29.

${ }^{4}$ Casi cincuenta variados escritos sobre el tema se recogen en LAZCANO, R., Bibliografia de San Agustín en lengua española (1502-2006), p. 459. 
Mi principal duda en este tema fue la traducción que se daba a la frase "tolle, lege, tolle, lege", Como es conocido, y se desarrolla más adelante, la palabra "tolle" lo mismo significa "quita, déjalo" que "toma". En el primer caso, déjalo, es patente y sin discusión, que tiene el significado señalado en la escena evangélica del juicio de Jesucristo ante Poncio Pilato, y es el pueblo que grita "tolle, tolle, crucifige eum" en la versión latina de La Vulgata ${ }^{5}$. Puede traducirse por la exclamación española ¡fuera, fuera, déjalo ya! ${ }^{6}$. En el segundo caso, también en un contexto evangélico, cuando Cristo dice a quien desee imitarle "tolle crucem tuam et sequere me" la tradución suele ser "Toma tu cruz y sígueme". Por tanto, la cuestión que se debate es si "Tolle, lege" debe ser entendida como "toma y lee", es decir toma las Escrituras y lee su mensaje o "déjalo, lee" es decir, abandona ahora ya tus dudas y sigue el mensaje de la Escritura. No atañe para nada en el asunto de la conversión. Afecta a un detalle en razón de la palabra escrita por san Agustín, a quien no podemos consultar para que nos diera la razón y sentido auténticos. Por eso empecé hace años buscando en toda la obra agustiniana cómo se utiliza y qué sentido se le da a la palabra tolle y sus variantes. La labor entonces fue larga pues no se contaba con los medios que hoy nos ofrece la tecnología. Más adelante veremos si ha servido para algo positivo esas citas de las obras de san Agustín. Manifiesto ya ahora, que no me convence de ninguna manera la traducción de la frase "tolle, lege; tolle, lege" que siempre se ha mantenido en español como "Toma y lee, toma y lee", que además de repetirse en cualquier ocasión, son palabras utilizadas como lema en escritos, en paneles, en edificios o como resumen de la bella, íntima y sublime escena de la Conversión de san Agustín. No es cuestión baladí el constatar que en la frase latina no existe ninguna conjunción, y en la traducción tradicional, se ha añadido gratuitamente la " $y$ ". Como detallamos más adelante, dicha conjunción contribuye a formar, más bien a transformar, una idea en una única frase con dos verbos en imperativo, que se diluyen en el sentido siguiente: que se lea lo que se le ha ofrecido. Sin la conjunción, las dos palabras o dos verbos son dos ideas en tiempo verbal imperativo con su propia finalidad y sentido. Ambas tienen una cierta relación en la praxis, pero no en la forma gramatical. Es claro que el añadir la conjunción en una traducción puede tener tal importancia que hace desvirtuar el sentido de la frase original. Opinamos que esto ha sucedido al traducir Confesiones VIII,12,29.

5 Jn. 19,15. La frase griega "âron, âron" se tradujo al latín por "tolle”. Vocablo que figura también, por ejemplo, en el milagro al paralítico narrado en el mismo evangelio de san Juan (5,8): "Surge, tolle grabatum tuum, et ambula". Sobre este pasaje, sin embargo, algún exegeta plantea una duda basada en que Cristo, ferviente judío, no pudo decirle al paralítico "tolle" en el sentido de tomar o cargar, pues ese día era Sábado, y estaba prohibido trasportar cualquier peso.

${ }^{6}$ Jn. 19,15 . 
No se discute aquí el sentido y alcance de la conversión de san Agustín. En primer lugar, no tengo en cuenta, y por eso, prescindo totalmente del significado que algunos han dado, y aún mantienen incansablemente, a la "la escena del huerto" o, más bien "escena del jardín" como una conversión al estilo de la sucedida a san Pablo en su camino a Damasco. Todos esos autores vienen a desarrollar su opinión haciendo un paralelismo con lo narrado en los Hechos de los Apóstoles sobre Saulo de Tarso. Es decir, si Saulo en aquél momento de perseguidor de cristianos, por medio de una instantánea luz con el sonido de una voz divina, abandona su furor instigador, para convertirse en incansable apóstol de Cristo, de semejante manera Aurelio Agustín, en un jardín de Milán, abandona sus dudas, $\mathrm{y}$ al escuchar una infantil voz que le dice "tolle, lege; tolle, lege", tras la lectura de las palabras de san Pablo (Rom. 13,13), ciertamente decide bautizarse, pero ya con la firme decisión de ponerse al servicio de Dios. Pero digamos que si la tradición pictórica ha representado abusivamente que Saulo en su conversión cayera de un caballo, en el presente caso una cierta tradición literaria ha insistido en que, tras postrarse Aurelio Agustín bajo una higuera y leído un pasaje de las cartas de san Pablo, resuelve dedicarse a una vida de servicio, según el mensaje evangélico: deja todo lo que tienes y sigueme (Mat.19,21). Con el respeto debido a estas interpretaciones, no contemplo dedicarme ni a oponerme ni a conjeturar más extensamente sobre esta concreta interpetación. Que la meta de Aurelio Agustín es dedicarse al servicio de Dios, según hemos dicho, en una vida célibe, claramente él mismo lo manifiesta en Confesiones VIII,10,25: "Cuando yo deliberaba en ponerme e al servicio (consagrarme) del Señor, Dios mio, conforme hacía ya mucho tiempo lo había dispuesto, yo era el que quería, yo el que no quería: yo era" $"$.

Puede el lector, entonces, preguntarse si esto quiere decir que no comparto con algunas traducciones ni con ciertas explicaciones que se han dado y siguen dándose a puntos concretos de las Confesiones de san Agustín. Si he explicado bien esta duda, exactamente quiero decir que existen algunas frases importantes, a las que ya me opuse y deseo seguir oponiéndome. Es una humilde y nimia aportación ante la inmensa producción de traductores y comentaristas que se dedican a la obra escrita de san Agustín, la mía, modesta, no deja de tener su importancia. En todo caso, mi deseo es ayudar a entender mejor la mente del santo de Hipona.

7 "Ego cum deliberabam, ut iam servire Domino Deo meo, sicut diu disposuerams, ego eram, qui volebam, ego, qui nolebam: ego eram". Confesiones VIII,10,22. En la traducción de la edición BAC aparece la palabra "Consagrarme", tal como hemos copiado en el texto (entre paréntesis). Sin embargo, ese término nunca es utilizado por san Agustín, porque se deriva del latín eclesiástico posterior. 
No es ésta la primera vez que he comprobado errores en la traducción de esta gran obra agustiniana, me refiero en concreto a la publicada por la Editorial BAC. Alargarme en señalar incluso otras de las múltiples traducciones que existen no es un tema que desee abordar ni tampoco me atrae ${ }^{8}$. Tengo el honor de poseer la primera edición crítica y bilingüe de la editorial BAC., que un pariente mío me regaló cuando yo tenía 16 años, hace ya 70. Adquiere un valor fundamental al ser su autor el agustino P. Ángel Custodio Vega Rodríguez (1894-1972), excelso e incansable investigador que tanto ha honrado a su Monasterio de San Lorenzo de El Escorial, donde vivió durante casi toda su vida. El libro siempre ha estado conmigo y poco tiempo en su lugar en la estantería. Las anotaciones que yo he hecho en sus páginas durante tantos años son numerosas. Por otra parte, en las ediciones siguientes de Confesiones de la BAC, a través del tiempo, el texto se ha repetido y algunas veces se ha mejorado. Por casualidad se me encargó hacer la recensión de la edición de Confesiones de la misma Editorial del año 2019, a lo que me comprometí y manifesté que lo haría a conciencia. Señalé que, para ello, indicaría inclusive lo que yo ya había detectado en mi ejemplar del año 1946. Comprobé que inclusive algunos errores se mantenían, y como muestra, por cierto, señalé algunas de las que estimo deficiencias de esta primera edición y que en las muchas posteriores de la BAC no se han corregido ni detectado, incluida la última del año 2019, y cuya recensión publiqué en La Ciudad de Dios ${ }^{9}$.

Una de las dudas que se me planteó fue la traducción tradicional, siempre en mi personal criterio, de la frase latina "fecisti nos ad te, et inquietum est cor nostrum donec requiescat in te", habitualmente traducida "Nos has hecho "para"ti, y nuestro corazón está inquieto hasta que descanse en Ti"10. Entonces decidí analizar todas las palabras latinas del Capítulo 1 del Libro I, que se fue transfomando en un libro, en el que, entre otras muchas aclaraciones de las frases que lo forman, defiendo que en la frase anterior no debe traducirse como "nos hiciste para Ti..." que conlleva, suena, o se entiende como un inadecuado tufillo egoístico o recreativo referido a Dios. Por lo que, huyendo de tal desatino, quise evitar semejante sensación y traduje el ad te latino en un sentido dinámico, significado gramatical y propio de la preposición "ad" (hacia), en consonancia con el contexto de la frase "nos hiciste, Señor hacia ti, y nuestro corazón está inquieto hasta que descanse en ti". Traducción más adecuada y auténtica asumiendo la interpretación normal de la preposición ad, pues no me explico la razón por la que dicha preposición se haya de

\footnotetext{
${ }^{8}$ Numerosas versiones al español Cfr. LAZCANO, R., Bibliografía de San Agustín en lengua española (1502-2006), pp. 121-128.

9 VILLEGAS RODRÍGUEZ, M., "Recensiones", en La Ciudad de Dios 233-3 (2020) pp.973-981.

${ }^{10}$ Confesiones I, 1,1 .
} 
traducir "para ti". Y aunque no he comprobado éxito ni aceptación alguna -por escrito- ni que hayan sido atendidas mis razones, ahí queda argumentada también la importancia del capítulo I del Libro I de Confesiones como una síntesis organizada de todos los trece libros que contiene la obra. Pues el Creador, ciertamente, nos hizo seres dinámicos que se dirigen hacia ÉL, atraídos por Él. Todo esto se expresa muy bien en la frase agustiniana "hacia Ti". Porque, mientras, es decir, en esta vida, "nuestro corazón está inquieto hasta que descanse en $T i{ }^{\prime \prime}$.

En otra ocasión fue el inicio del libro X de Confesiones en el que se lee "Cognoscam te, cognitor meus, cognoscam sicut et cognitus sum", con una traducción al español muy generalizada de la forma siguiente: "Conózcate a ti, Conocedor mío, conózcate a ti como soy conocido". Recapacitando sobre esta traducción, juzgué que era defectuosa porque el contexto agustiniano trata sobre la vida en el "más allá" ya que cita a san Pablo en 1 Cor, 13,12. Y concluí, ciertamente, que había de traducir el cognoscam como futuro de indicativo: "Te conoceré". La dedicación a este detalle dio lugar a un artículo, con suficiente argumentación para tenerlo como la más correcta traducción de la palabra cognoscam. Una breve conversación que sostuve sobre este tema con el encargado de actualizar las varias y seguidas ediciones de las Confesiones en la editorial $\mathrm{BAC}$, resultó eficaz para que así apareciera en la que llaman tercera de la BAC del año 2019. También alude en nuestra conversación a la traducción de la frase "Pondus meum, amor meus..." que se encuentra en Confesiones XIII,9,10. Pero desilusionado, vi que el capítulo 9 del Libro XIII llevaba el título "Mi amor es mi peso", sin atender a que en el texto de ese capítulo se había correctamente traducido como "mi peso es el amor".

A propósito de esta frase agustiniana, he de añadir aquí que mantengo en su traducción la palabra española "peso" porque entiendo que se ha de explicar al lector benévolo el valor y sentido de esta palabra, pues el principal significado, con el que figura en el Diccionario de la Real Academia Española, no suele ser conocido habitualmente. No hay duda que en español se entiende mejor si en lugar de peso se dice atracción o fuerza, ya que estamos habituados a hablar de la "Ley de la gravitación universal" de Newton en relación a la fuerza de atracción. $\mathrm{O}$ acaso mi atracción entendida como una fuerza y energía tal que hace captar cuanto se percibe como algo bueno y deseable ${ }^{12}$.

Entiendo la dificultad intrínseca que tiene el traducir una obra latina, antigua y plena de ideas y principios filosóficos y teológicos. Toda traducción se presta

\footnotetext{
11 VILLEGAS RODRÍGUEZ, M., Análisis de Confesiones (I,1) de san Agustín, San Lorenzo de El Escorial 2018, pp.224

${ }^{12}$ Cfr. Ibídem, p. 979.
} 
a muchos errores, y a muchas opciones posibles, y no es tema a resolver por fórmula matemática. Pero, evitando cualquier velada y agria crítica en una sencilla corrección, se impone señalar aquellas deficiencias que pueden alterar el sentido original del texto. Este ha sido mi fiel interés. Cualquier otra interpretación que lo califique de hiriente está lejos de mi intención. Entiendo, además, que las sencillas correcciones en cosas puntuales no dejan de tener una mínima importancia ante la visión y comprensión total del pensamiento, en este caso, agustiniano.

Por tanto, en este artículo mi decisión de investigar el Libro VIII de Confesiones y proponer mis percepciones o mis lógicas deducciones están muy lejos de querer crear mayor confusionismo sobre este tema tan manido. Si algo queda aclarado, no dudo que la intuición y la iluminación, ambas dimanantes de Dios, van parejas. Todo es posible. El autor es el exclusivo responsable de sus propios errores. Así pues, resalto y acentúo sobre todo los diversos hechos y reflexiones que aparecen en el libro VIII de Confesiones que entiendo tienen su repercusión peculiar en la famosa escena del "Jardín de Milán", tal como está descrita por san Agustín. Porque no hay duda alguna que esa famosa escena está narrada por el autor como el fruto o consecuencia de los factores que él mismo relata anteriormente. Todo el Libro VIII está armoniosamente trazado para llegar, llamémoslo así, a la gran y vital decisión de Agustín y Alipio. Quizás se pudieran añadir aquellos pasajes que aparecen en los libros anteriores, pero, como queda dicho, yo elijo aquí expresamente las referencias que llevan a san Agustín a señalar en el Capítulo XII del Libro VIII, la determinación incondicional de su entrega personal al servicio de Dios.

\section{REFLEXIONES DE SAN AGUSTÍN}

En este libro VIII narra san Agustín, lo que podemos calificar como el hecho de mayor importancia en su vida, que él considera debe exponer públicamente para que trascienda en beneficio de quien lo leyere para que todos juntos adoren a Dios, Le bendigan en el Cielo y en la tierra y Le confiesen como "El Grande y sumamente digno de toda alabanza", es decir, reconocerLe en su Deidad ${ }^{13}$.

${ }^{13}$ Toda esta introducción se conecta con el Libro I,1,1. "Eres el Grande, Señor, y sumamente laudable". El tiempo me ha llevado a evitar, cuando puedo y me acuerdo, decir de Dios palabras que son adjetivos. Por eso anteponiendo el artículo El Grande deseo evitar predicar de Dios algo que contiene "una graduación". Acerca del libro I, Capítulo $1^{\circ}$. Cfr. mi comentario: VILLEGAS RODRÍGUEZ, M., Análisis de Confesiones (I,1) de San Agustín, San Lorenzo de El Escorial 2018, pp.55-64. 


\subsection{Reflexión 1 : La misericordia de Dios (Confesiones VIII,1,1)}

San Agustín señala a Dios como el Autor primero y principal de su conversión. Las primeras frases contienen todas las características del saludo inicial en una perfecta pieza retórica.

COMENTARIO: Comienza el libro VIII con citas de salmos que es la forma usual de iniciar cada libro de esta obra. Agradece que la misericordia de Dios rompiera las cadenas que le ataban. Por eso, Le ofrecerá un sacrificio de alabanza (Salmo 115,16-17). No ocultará el secreto en su corazón pues contará a todos cómo el Señor rompió sus ataduras, para que todos los que adoran a Dios, cuando lo lean, digan: "bendito es el Señor, grande y admirable es su nombre" (Salmo $75,2)$. Las palabras de Dios se le han adherido hasta en lo más hondo de sus entrañas y experimenta "la especial sensación de estar rodeado de y por Dios".

Impresiona la lectura de estas palabras: "Dios mío, que yo te recuerde en acción de gracias y confiese tus misericordias sobre mí. Que mis huesos absorban tu amor y digan: ¿quién semejante a ti?" (Salmo 34,10) ${ }^{14}$. Los dos verbos -recorder y confitear- indican dos actitudes fundamentales que el hombre ha de manifestar ante Dios: Lo primero que san Agustín tiene presente en su memoria-corazón -recorder- es un agradecimentto hacia Dios, que conlleva una firme voluntad de señalar los bienes que de Él ha recibido, recibe y recibirá, es decir, todo cuanto tiene proviene de la Bondad dadivosa de Dios. Para completar esta idea, aunque en definitiva se incluye también en el verbo anterior, san Agustín expresa con confitear, su profundo agradecimiento, que no es otra cosa que reconocer la Misericordia que siempre Dios ha mantenido en su favor. Estas dos ideas unidas vienen a ser completadas muy expresivamente con el verbo perfundantur: "perfundantur dilectione tua" (absorver y empapar de amor) que aplicado a los huesos sugiere tal trasformación de la dureza humana a una fina sensibilidad ante el Señor, que desvela la firme correspondencia del alma agustiniana hacia Dios y ante los hombres.

Así pues, eleva una gran, profunda y agradecida invocación hacia Dios porque ÉL es el autor primero y principal de la conversión de Aurelio Agustín.

14 "Deus meus, recorder in gratiarum actione tibi et confitear misericordias tuas super me. Perfundantur ossa mea dilectiones tua et dicant: Domine quis similis tibi?". El P. Vega dice en la nota n.2 (p.650) en la Edición BAC 1946 que San Agustín tiene un bello comentario sobre este versículo 13. Pero solamente indica el versículo omitiendo el número del salmo. Y se lee (In Ps., 13), que para mí es un error interpretativo de la imprenta, pues se refiere al Ps.34,13. Este lapsus, es decir, omiitir el Ps. 34 ha ocasionado un error continuado, incluso en la edición BAC 2019, en donde la nota 2 de la p.259 se lee "Espléndido comentario a este versículo bíblico (In Ps.,13). 
De forma gozosa se propone contar cómo Dios intervino para romper las ataduras que le tenían sujeto e inmóvil, pues las palabras divinas se habían adherido a sus entrañas y se sentía acorralado: permítaseme transcribir esta última idea con las palabras originales escogidas por san Agustín pues resuena en ellas mismas una armoniosa y trepidante cadencia musical: "Inhaeserant precordiis meis verba tua et undique circumvallabar abs te" 15 .

Plantea a continuación la fundamental diferencia entre el conocimiento que tiene de la naturaleza divina y la de su propia indigente naturaleza. Indica cuál es el grado de su conocimiento respecto de Dios y lo desea resaltar. San Agustín conoce que Dios es la VIDA, eterna e incorruptible, de la que procede toda sustancia. Tenía certeza de ello, pero, sin embargo, era consciente de que su conocimiento era inestable. Expone también cuál es el conocimiento de sí mismo que quiere manifestar y hacerlo público, pues su vida es temporal, llena de vacilaciones. Pero comprendiendo ya el camino que es Cristo, tenía pereza por causa de una exagerada exigencia que él imaginaba contenía el itinerario evangélico ${ }^{16}$.

\subsection{Reflexión $2^{a}$ : Visita a Simpliciano (Confesiones VIII, 1,1-5,12).}

La influencia de la visita a Simpliciano tiene gran importancia en la decisión de Aurelio Agustín. Es una narración amplia y completa, ya que se extiende desde el Capítulo $1^{\circ}$ al Capítulo $5^{\circ}$ (Confesiones VIII,1,1-5,12). La entrevista con Simpliciano, a quien abre humildemente su trayectoria de vida y los íntimos sentimientos de su corazón, es narrada con gran belleza y profunda sinceridad. San Ambrosio consideraba a Simpliciano como "el padre" de su vida espiritual. Y de la lectura de las Confesiones se puede concluir que la relación de san Agustín y san Ambrosio era respetuosa y amistosa, pero no la adecuada para esta especial clase de asuntos. Ateniéndonos a la realidad histórica, el hecho es que san Agustín considera que la intención de visitar a Simpliciano proviene de una inspiración divina ${ }^{17}$. Así pues, como él mismo relata, siente un profundo anhelo por visitar a Simpliciano a quien considera como la persona indicada para resolver sus dudas. Presenta un breve elogio a Simpliciano y tiene plena confianza

15 "Se empaparon mis entrañas de tus palabras y me sentía acorralado por Ti". Confesiones VIII, 1,1 .

${ }^{16}$ Esta reflexión agustiniana sobre la Vida de Dios y la vida del hombre (De vita tua aeterna... De mea vero temporali vita) (Confesiones VIIII,1,1). recuerda la famosa respuesta que se da él mismo en su obra Soliloquios acerca de lo que desea saber: "Deum et animam scire cupio" (Solo deseo conocer lo que es Dios y lo que es el hombre), Soliloquios I,2,7.

17 "Et immisisti in mentem meam visumque est bonum in conspectu meo pergere ad Simplicianum" Confesiones VIII,1,1. 
en sus consejos para caminar por y en la senda de Cristo. Le han contado que éste desde su juventud vivió devotamente y tiene una gran experiencia religiosa, siendo, pues, apto para dirigirle y ayudarle a superar su estado de ánimo y alcanzar el buen camino de Cristo.

Ante Simpliciano la actitud de san Agustín es impecable y ejemplar en la aceptación de la voluntad de Dios. Nos expone brevemente su situación anímica antes de entrevistarse con él. Señala que la Iglesia se le presenta como maestra liberal respecto de la forma de vida a elegir. Le desagrada lo que estaba dedicado a hacer "in saeculo" y que lo soportaba como una carga pesadísima. De estas palabras parece deducirse que no tenía intención ya de seguir en su oficio como profesor de Retórica. No deseaba ni honores ni dinero: Ha superado parcialmente aquella etapa en la que "anhelaba los honores, las riquezas y el matrimonio" que nos narra en el libro VI de Confesiones ${ }^{18}$.

La visita a Simpliciano es de fundamental importancia para Aurelio Agustín. Al referir éste que había leído algunos libros platónicos traducidos al latín por Mario Victorino, retórico en Roma, Simpliciano se alegró y le felicitó por no haber dado con otros filósofos falaces y engañosos. Este hecho ofrece a Simpliciano la oportunidad de narrar que, cuando él estuvo en Roma conoció muy bien a Victorino y tuvo una gran amistad con él, habiéndole dirigido previamente en su conversión al cristianismo. Victorino decía frecuentemente a Simpliciano, que ya era cristiano, y éste insitía que quería verle entre los fieles en una Iglesia, y aquél mostraba un fino sentido del humor con la "burla de las paredes" al contestar a Simpliciano: "iqué! ¿son las paredes las que hacen al cristiano?" 19 . En realidad, Victorino, en esos momentos, al convertirse al cristianismo temía ofender a sus amigos que pudieran convertirse en enemigos.

18 "Inhiabam honoribus, lucris, coniugio, et tu inridebas" Confesiones VI,4,9. La frase elegida es muy significativa, pues el verbo latino utilizado (inhio) tiene el tono codicioso de anhelar. Muchas otras citas hacen referencia a este tema: "Carecer de las caricias de la mujer: "si feminae privarer amplexibus" Confesiones. VI,11,20. Alipio le prohibía tomar mujer: "Prohibebat me sane Alypius ab uxore ducenda" Confesiones VI,12,21. Santa Mónica insiste en que se casara: "Et instabatur impigre, ut ducerem uxorem" Confesiones. VI,13,23, La discusión acerca de la aceptación o no de la presencia de la mujer impide que se haga realidad la sociedad comunitaria que quisieron formar un total de 10 amigos con san Agustín, "....utrum hoc mulierculae sinerent" Confesiones VI,14,24. Se une a la madre de Adeodato, y le es fiel: "In illis annis unam habebat non eo quod legitimum vocatur coniugio cognitam..ei quoque servans tori fidem", Confesiones IV, 2,2. Obligado a abandonar a la madre de Adeodato, se procuró otra mujer, sin casarse con ella: "procuravi aliam, non utique coniugem animae meae satellitio perdurantis consuetudinis in regnum uxorium", Confesiones VI, 15,25. Se pregunta, si la buena voluntad puede compararse a las riquezas, a los honores y a los placeres del cuerpo: "Quantis pendis oro te, hanc voluntatem? Numquid si ulla ex parte divitias, aut honores, aut voluptates corporis aut haec simul omnia conferenda arbitraris? De Libero arbitrio, I,12,25). Véase entre otros pasajes De Libero arbitrio, I,15, 31.

${ }^{19}$ Confesiones VIII,2,4. 
Algo semejante se produjo en el interior de Aurelio Agustín, y por eso, le favoreció su prolongada estancia en Casiciaco. Le influye, como le influyó a Victorino el pasaje del evangelista san Mateo 10,33: "Quien me negare delante de los hombres, yo también le negaré delante de mi Padre, que está en los Cielos" ${ }^{20}$. Y fue después de leer Lc 12,921 que meditó y se fortaleció, y acudió a Simpliciano a notificarle que quería ir a la Iglesia a dar su nombre para su bautismo. Llegada la hora de profesar la fe, rehusó la oportunidad que le ofrecieron los sacerdotes de proclamarla en secreto, y cuando los fieles dejaron de vitorearle, no temió ante la grey al pronunciar con voz de gran retórico la fe en Cristo, quien nunca rehusó ante las turbas vociferar sus discursos vanos. Los fieles aclamaron su nombre " $i$ Victorino, Victorino!".

Habiendo narrado Simpliciano a san Agustín cómo Victorino no se avergonzó de ser siervo de Cristo, sojuzgando su frente al oprobio de la cruz, y no obstante haber llegado con anterioridad a merecer una estatua en el Foro Romano, Aurelio Agustín ve un ejemplo que le impulsa para decidirse él dada la similitud de coincidencias entre ambos. Es también de suponer que existieron además conclusiones ideológicas y prácticas, consejos y opiniones personales que Simpliciano le trasmitió, pero que no son expresamente referidas por san Agustín. Es claro que éste estimó que Simpliciano fue una importante ayuda para la inestable situación anímica por la que atravesaba.

Por lo tanto, una vez que Aurelio Agustín acepta y pone en práctica la inspiración recibida para visitar a Simpliciano. le narra brevemente sus "circuitus errores mei"22. Le confiesa su disgusto y rechazo a su actual actividad académica y aunque no le atraen ni los honores ni la riqueza ${ }^{23}$, se sentía ligado a la vida conyugal, aunque entendía también el valor del celibato como margarita preciosa $^{24}$, y esto le ocasionaba indecisión y -dice muy expresivamente"dubitabam" (dudaba, vacilaba) ${ }^{25}$.

San Agustín reflexiona sobre el penitente y el hombre justo. y sobre la alegría de encontrar lo perdido, cosas y personas ${ }^{26}$. Es claro que según las mismas palabras de san Agustín, él deseaba imitar a Victorino, y coincide, sin duda,

${ }^{20}$ Lugares paralelos: Lc 12,9; Mc. 8,38; 9;

${ }^{21}$ Ibídem.

${ }^{22}$ Confesiones VIII,2,3.

23 "Non iam inflammantibus cupiditatibus, ut solebant, spe honoris et pecuniae...non delectabant prae dulcedine tua et decore domus tuae quam dilexi" Confesiones VIII,1,2.

${ }^{24}$ Mt. 13,46,

25 "Sed ego infirmior eligebam molliorem...bonam margaritam, et venditis omnibus, quae haberem, emenda erat, et dubitabam". Confesiones VIII,1,2. Su duda se opone a la afirmación y a la negación.

${ }^{26}$ Confesiones VIII, 3,6-4,9. 
con la intención de Simpliciano al contárselo. El mismo san Agustín narra que entonces consideraba a Victorino dichoso porque no pudo seguir enseñando en su escuela ${ }^{27}$.

Avanza velozmente hacia la Luz con la lectura de Gálatas 5,17, que la carne apetece contra el espíritu, "estando yo -dice- en ambos". Tiene una percepción clara y cierta de la verdad. Y además, se sentía dulcemente oprimido por la carga del siglo y decía: "me veía sometido y con pereza para superar esa opresión, y me repetía: ahora, en seguida, un poquito más. Pero este ahora no tenía término y este poquito más se iba prolongando" ${ }^{28}$. Compara su actitud al sueño que tienta al que debe levantarse.

\subsection{Reflexión $3^{a}$. La visita de Ponticiano (Confesiones VIII,6,13-7,18)}

Narra san Agustín de qué forma Dios le libró de la atadura y ardiente impulso que mantenía por las relaciones carnales y por la servidumbre de los negocios seculares. En esta fase trata sobre su estado anímico respecto a la fuerza que él siente se le opone y a la que no está obligado a superar. Esto último es digno de ser resaltado cuando se expone la conversión de Aurelio Agustín, porque se puede decir que no se trata de aceptar la fe cristiana, pues esta meta la tiene prácticamente alcanzada. Tiene conciencia, por otra parte de que Alipio, desde hace tiempo parece ya haber resuelto el tema del celibato. Sin embargo, él se enfrenta a un compromiso matrimonial elegido por su madre, al que éste no sabemos se haya opuesto. Ahora le nace un sentimiento profundo por imitar a Victorino. Cuenta con la compañía de Alipio, y los dos en ese momento concreto continúan con su ocupación diaria de vender consejos (Alipio), con la facultad de hablar (Agustín) y, además, Nebridio dedicado a ayudar al amigo común Verecundo ${ }^{29}$. Es una afirmación interesante la que deja reflejada en Confesiones al decir que "una angustia creciente le invadía al hacer las cosas de costumbre, pero visitaba la Iglesia y suspiraba por Ti" ${ }^{\prime 30}$.

Una visita de Ponticiano a Aurelio Agustín y a Alipio se produce en la domus milanesa y le reciben en el Tablinum ${ }^{31}$. Cuál fue el motivo de esta visita no se puede saber pues san Agustín parece que evita decirlo. Como

${ }^{27}$ Confesiones VIII, 5,10.

28 “...modo, ecce modo, sine paululum. Sed modo et modo non habebat modum et sine paululum in longum ibat" Confesiones VIII,5,11-12.

29 "Nebridius autem amicitiae nostrae cesserat, ut omnium nostrum familiarissimo Verecundo, medionalensi et civi et gramático subdoceret, vehementer desideranti et familiaritatis iure flagitandi de numero nostro fidele adjutorium quo indigebat nimis" (Confesiones VIII,6,13).

${ }^{30}$ Confesiones VIII, 6,13.

${ }^{31}$ Normalmente es la pieza de la casa que hoy denominamos sala de estar, y se encontraba entre el atrium y el hortus 
Ponticiano ve un códice sobre una mesa, abre sus páginas creyendo que trataba de Filosofía, Gramática ó Retórica, y se encuentra con que contiene la carta de san Pablo a los Romanos y acaso alguna otra de sus cartas. Se alegra que sea así, y ante la manifestación de san Agustín de que dedicaba su máxima atención a esa lectura, Ponticiano comienza a hablar de la gran figura de san Antonio (250-356), monje de Egipto, y se admira que no hubiesen oído nunca nada acerca de este monje. Quedan estupefactos comprobando tan grandes maravillas, tan recientes y cercanas a aquellos sus tiempos sin conocerlas. Ponticiano, sigue narrando que muchos cristianos viven en monasterios en los desiertos del yermo, y que mismamente en Milán hay un monasterio, bajo la dirección de Ambrosio, a las afueras de la ciudad, cuestión que ambos amigos desconocían ${ }^{32}$.

Ponticiano se alarga en su narración y viene a contar que, estando él en Tréveris, mientras el emperador presenciaba los juegos circenses de la tarde, salío a pasear con otros tres compañeros ${ }^{33}$ por los jardines contiguos a la muralla, yendo él y otro por un camino y los otros dos por camino diferente. Estos dos vinieron a dar en una "casam" ${ }^{34}$. Dentro encontraron un códice que contenía la vida de san Antonio, que uno comenzó a leer, a admirarse y encenderse tanto que pensó en abrazar aquel género de vida, "abandonando la milicia del mundo, servirte a ti sólo". Finalmente dijo a su amigo "he resuelto dedicarme al servicio de Dios, y lo quiero comenzar en esta misma hora y en este lugar. Y alli se quedarton ambos y comenzaron a edificar la torre evangélica con las justas expensas del abandono de todas las cosas y de tu seguimiento" 35 .

Ponticiano y el otro amigo, ante la tardanza de los nuevos conversos, les buscaron y encontraron, por fin, en ese lugar, y sumamente tranquilos. Ponticiano dijo que: "lloránrose a sí mismos y les felicitaron piadosamente y se encomendaron a sus oraciones, ponienso su corazón en la tierra. se volvieron a palacio. Mas aquellos, fijando el suyo en el cielo, se quedaron en la cabaña. Los dos tenían prometidas, pero cuando oyeron éstas lo sucedido, consagraron su virginidad ${ }^{\prime 36}$.

${ }^{32}$ Confesiones VIII, 6,14

${ }^{33}$ Confesiones VIII,6,15. La palabra latina que figura en el texto es "contubernales" que propiamente significa compañeros que trabajan en un edificio consular, en este caso, palaciego. Cfr. ERNOUT, A- MEILLET, A., Dictionnaire etymologique de la langue latine, Klincksieck, Paris 2001.

${ }^{34}$ Es correcto el sentido que San Isidoro de Sevilla da a la palabra latina "casa": "Casa, es una habitación rústica formada por palos y cubierta de caña y malezas para defenderse del frio y del calor": Etimologías, L.15, c. 12, 1, Ed. BAC, Madrid 1951, pág. 379. Se refiere también a una barraca un tanto amplia, estilo militar ya que en ella habitaban, como dice san Agustín en este pasaje, "ciertos siervos tuyos". Incluso signífica lo que normalmente se entiende en español por una granja.

${ }^{35}$ Confesiones VIII, 6,15.

${ }^{36}$ Confesiones VIII, 6, 15. 
Mientras Ponticiano hablaba Dios le trastocaba. Comenta él: "quitándome de mi espalda, donde yo estaba colocado para no verme, y poniéndome delante del rostro para ver mis miserias... No tenía ya dónde huir de mí mismo. Conocia mi iniquidad y la odiaba, pero la disimulaba y la olvidaba... Me odiaba a mi y amaba ardientemente a los que eran un ejemplo. Me odiaba a mí mismo al compararme con ellos ${ }^{\prime 37}$. En mirada retrospectiva, san Agustín señala que hace 12 años, cuando tenía 19 de edad, leyó el Hortensio, que le arrastró hacia la Sabiduría. Le pidió al Señor la castidad, pero temiendo ser escuchado, añadía "no todavia", pues prefería saciar su concupiscencia antes que extinguirla ${ }^{38}$. Se excusaba diciéndose que tenía incertidumbre de la verdad y por eso no quería descargarse de su vanidad, con la queja de que otros sin meditar los más de 10 años, como él hizo, pudieran libremente elevarse. Lo escuchado de Ponticiano le corroe el alma, y agotados sus falaces argumentos, aún quedaba en su alma un mudo temblor con miedo mortal a romper con la costumbre que le conducía a la muerte ${ }^{39}$.

\subsection{Reflexión 4a: La indecisión en Aurelio Agustín (Confesiones VIII,8,19- $11,27)^{40}$}

Las importantes reflexiones de san Agustín merecen ser desmenuzadas y comentadas. Es primordial, desde el punto de vista narrativo, ahondar en estos capítulos para entender mejor la angustia real que sufrió Aurelio Agustín mientras va camino de convertirse en el Obispo de Hipona. Él desea asumir el mensaje total de Cristo, ponerlo en práctica sin rebajas de ningún género. Buscará y hallará la ayuda divina que necesita. Profundizar sus palabras anteriores a la narración de la escena del jardín es absolutamente necesario para percibir con suma claridad la dificultad y, al mismo tiempo, trascendencia de su conversión, una conversión plena.

${ }^{37}$ Confesiones VIII, 7,16.

${ }^{38}$ Confesiones VIII, 8,17. Por lo tanto tenía entonces 31 años.

${ }^{39}$ Confesiones VIII, 8,18 .

${ }^{40}$ En todas las ediciones de Confesiones de la BAC, desde la primera a la última (BAC 1964, nota 39, p. 655 y BAC 2019 nota 28, p. 285) lo escrito por san Agustín en los capítulos 8,19-11,27 es considerado como una interrupción arbitraria en el relato histórico de la escena del jardín. Afirmación que no comparto en absoluto, ya que san Agustín decide detallar genialmente sus respuestas en las que subyace un gran valor analítico y didáctico en consonancia con el actual conocimiento de la psique, y explica las dificultades que tuvo que vencer en aquel momento y cómo -de forma retrospectiva- está magníficamente detallado. Por tanto, su denso contenido tiene un especial valor para entender mejor el instante de su conversión. Para esta breve alusión psicológica Cfr.: DE LA VEGA, M., Introducción a la Psicología cognitiva, Ed. Alianza-Psicología, $7^{\mathrm{a}}$ reimpresión, Madrid 1994, Apartados 9.2 y 9.3 -Razonamiento inductivo- pp- 467-514. 
El relato de Ponticiano le produjo a Agustín un vehemente desequilibrio en lo más profundo de su ser, alma y corazón, (equivalente en la Psicología al pensamiento y la emoción) turbando tan fuertemente su mente que se reflejó en la expresión de su rostro. Desconcertado y con ciego impulso se precipitó sobre Alipio ${ }^{41}$ y le gritó: “¿Qué nos pasa? ¿Qué es esto que has oído? ¡Se levantan los indoctos y nos arrebatan el cielo y nosotros con nuestra alta ciencia carente de corazón, nos enfangamos en la carne y en la sangre!?"42. Son palabras de un intelectual Aurelio Agustín perplejo, pero se necesita mucha humildad y sinceridad del obispo de Hipona para hacer un retrato del gran personaje, de sí mismo, lleno de envidia y clasismo intelectual.

Por el modo en que se analiza, san Agustín narra con formas tajantes y casi irracionales, cómo en medio de una vehemente lucha interior se enfrentaban corazón y alma ${ }^{43}$. Y con un ciego impulso, como se ha señalado anteriormente, le gritó a Alipio. No encuentra reposo interior ¿Es envidia y humillación? Es como si le hubieran arrebatado algo de su exclusiva propiedad. No son meramente excesos retóricos. Y suavizando su incontrolada queja, en un inicio de raciocinio susurró a Alipio que, al menos ellos dos, debieran imitarles. No pudo ocultar su raíz bereber, mesándose su cabello y golpeándose la frente, sus ojos, mejillas, su tono de voz desvariaba, mientras su amigo, con mirada perpleja, estupefacto, permanecía en silencio. El descontrol de su corazón le hace salir al jardín para afrontar ese arrebato en lugar lo más lejano de la casa. Le acompaña Alipio... ¿cómo iba a abandonarle ahora? ${ }^{44}$. Con el códice de san Pablo en su mano, él y Alipio, se dirigen a sentarse en un banco del jardín. San Agustín señala la causa de su indignación porque no está unido al Señor, de grado o a la fuerza, cuando todos sus huesos deseaban clamar grandes alabanzas a Dios y Le ensalzaban hasta el cielo. Porque al cielo no se puede ir en una cuadriga, ni en una nave, ni andando ${ }^{45}$, sino con simplemente querer ir, sin

41 "Invado Alypium" dice el texto de forma muy impulsiva. Confesiones VIII,8,19.

${ }^{42}$ Confesiones VIII,8,19. Este pasaje de Confesiones VIII, 8,19, magnífico por su literatura y retórica, es, además y especialmente, una introducción y planteamiento del problema a resolver en los capítulos 9,10 y 11 , que conectan perfectamente con el capítulo 12 en donde sucede la escena del jardín.

${ }^{43}$ Una buena exposición sobre el tema de las construcciones lingüísticas y sus efectos sobre la emoción Cfr. BELINCHÓN, M.; TODA, J.M., y RIVIÈRE, A., Psicología del lenguaje, Investigación teórica, Ed.Trota, Colección Estructuras y procesos y serie cognitiva, Madrid 2a Ed, 1994, pp. 291-317..

${ }^{44}$ Confesiones VIII, 8,19. La frase siguiente "Neque enim secretum meum no erat, ubi ille aderat" que se traduce en todas las ediciones de la. BAC de esta forma "pues, aunque él estuviese presente no me encontraba yo menos solo" en mi opinión es una versión confusa. San Agustín viene a decir, en mi opinión que: "no existía secreto mío en que él no estuviera presente", es decir, no tenía secreto para con Alipio. De hecho, el texto continúa así: “¿Cómo, pues iba él a abandonarme al verme tan afectado?".

${ }^{45}$ Confesiones VIII,8,19, 
más. Pero ¿cómo se consigue ese equilibrio si dentro de uno mismo una parte suya le hace caer y otra le levanta ${ }^{46}$.

Constata que en las expresiones corporales que llevó a cabo (mesarse los cabellos, golpearse la frente, entrelazar sus dedos, oprimir las rodillas), debilitado y paralizado por el sentimiento de angustia que le embargaba, se produjeron así porque quiso, pero pudiera no haber querido y la movilidad de su cuerpo no le hubiere obedecido. Eran reflejos de su innata cultura bereber. Le faltó el querer hacer desde una voluntad de querer y querer hacer, pues -dice- quería, pero no obraba. Es el hilo casi invisible que aún le ata. El alma manda al cuerpo, y obedece al más tenue mandato del alma, pero el alma en ocasiones necesita de ella misma una fortísima decisión ${ }^{47}$. Y esto le parece monstruoso.

Implora a Dios respuestas a estas misteriosas penalidades del género humano. Necesita la Luz misericordiosa para encontrar su contestación a las numerosas tinieblas de los hijos de Adán. Desea desentrañar el interrogante sobre la causa por la que el cuerpo obedece de inmediato al alma y el alma no se obedece a sí misma. Es el alma la que quiere porque ella quiere, pero no hay ejecución: querer no es actuar y sentir, Resuelve esta incógnita respondiéndose que es un mandato sólo parcial, y es deficiente en la medida en que la orden es débil. Es un desfallecimiento de la voluntad, y se puede decir que no ordena, puesto que no desea plenamente, y por eso no se llega a actuar. Si toda ella se implicara en la orden, no sería necesario ordenar, sería pura acción, plena decisión. Extrae otra consecuencia sobre la indecisión, cómo un desear a medias y no desear parece no ser otra cosa que una enfermedad. Entonces no hay monstruosidad alguna, He aquí, pues, la clave del sufrimiento humano. La lucha interior que desazona no permite serenarse hasta que no hay una resolución firme. La

${ }^{46}$ Confesiones VIII,8,19 que es, por su importante contenido digno de ser leído y meditado. Las palabras de la frase con que expresa su estado de ánimo son bellas y sonoras, de tal forma que no resulta fácil especificar cuando las palabras son reales o retóricas en su pretendido mensaje: "in illa grandi rixa interioris domus meae, quam fortiter excitaveram cum anima mea in cubiculo nostro corde meo, tam vultu quam mente turbatus...". Y sigue, cuando grita (clamo): "cum doctrinis nostris sine corde, ecce volutamur in carne et sanguine". Ciertamente tiene razón al afirmar más adelante: "Plus loquebantur animum meum frons, genae, oculi, color, modus vocis quam verba, quae promebam" (Y mucho más que las palabras que profería declaraban el estado de mi alma (animum meum). La frase esta copiada literalmente de la Edición de la BAC 1946 p.635, y ed.2019, p.283. Al traducir la palabra animus-i por alma, seguramente en razón de un acostumbrado aristotelismo (alma y cuerpo) se desvirtúa la parte del hombre por decirlo así más divina, que es el alma, sede especial del Espírtu Divino.

${ }^{47}$ Confesiones VIII,8,20. “...quam ipsa sibi anima ad voluntate, suam magnam. In sola voluntate perficiendam” (...que no el alma a sí misma para realizar su plena (grande) voluntad en la sola voluntad"). La traducción en la ed. BAC es obscura sin duda. Yo pienso que el texto viene a referirse a que en los casos más complicados para la voluntad (voluntad grande) ésta no puede llevarlo a cabo sin una especial ayuda de Dios. 
voluntad elevada por la Verdad, no se levanta completamente, pues se siente oprimida y asfixiada por la costumbre. Por eso, se puede hablar de dos voluntades, porque una no es completa por faltarle lo que tiene la otra. Son complementarias entre $\mathrm{si}^{48}$.

Desea aclarar la afirmación anterior para que no se interprete en un sentido maniqueo y aprovecha para tacharles de parlanchines seductores de mentes, pues no existen dos voluntades derivadas de dos naturalezas, una buena y otra mala. La maldad está en ellos, que son malos mientras eso sostienen y serán buenos cuando crean en la verdad de las palabras veraces de san Pablo "antes fuisteis tinieblas y ahora sois luz" (Ef 5,8). Pero quieren ser iluminados por la luz de ellos mismos y no por la Luz del Dios iluminador que ilumina a todo hombre que viene a este mundo (Jn 1,9). Desea dirigirles con su propio ejemplo, pues les decía que cuando (pensando como ellos) él titubeaba en servir a Dios, él quería y no quería. Quería no plenamente y plenamente no quería. Era consigo mismo que se causaba una íntima escisión, que él no deseaba y era, pues, como un castigo para su alma. El estar escindido adquiere en sus palabras un profundo significado porque afirma no ser él el "artesano", sino el pecado que habita en él, como castigo de Dios a los hijos de Adán ${ }^{49}$.

Sin citarles, sigue refutando la tesis maniquea de dos naturalezas una buena y otra mala, basada en las dos voluntades contrarias, con el argumento de que, al existir múltiples voluntades diversas y contrarias, habría entonces múltiples naturalezas contrarias. Si en el ejemplo de ir a una reunión o al teatro, ellos (los maniqueos) deciden que es una buena y la otra mala, no hay razón para esa conclusión. Y arguye: con otro criterio podría declararse las dos malas. Y para clarificar esto argumenta contra ellos: si un cristiano duda si ir al teatro o a la Iglesia, ellos, sin duda, si se atreven a decir que el ir a la Iglesia es una voluntad mala, se encuentran con que hay dos voluntades malas, el ir al teatro y el ir a la Iglesia. A no ser que se conviertan a la verdad y reconozcan que cuando el hombre delibera, lo hace con una sola alma agobiada entre voluntades contradictorias ${ }^{50}$.

En consecuencia, no deben concluir, cuando advierten en un hombre dos voluntades que se contradicen que hay dos mentes contrarias, dos sustancias contrarias y dos principios contrarios que se debaten entre sí, pues si el Señor les muestra que en ocasiones hay en un hombre dos voluntades malas, por ejemplo: matar con veneno o matar con espada, elegir entre robar a los propietarios de

\footnotetext{
${ }^{48}$ Confesiones VIII,9,21.

${ }^{49}$ Confesiones VIII,10,22.

${ }^{50}$ Confesiones VIII, 10,23.
} 
una u otra granja, o cometer un adulterio, y en el supuesto de querer todas esas cosas, querer ejecutarlas en un mismo tiempo, esas dos, o tres o cuatros y más que podemos añadir para realizarse, lo que hacen es despedazar el alma, pero no se pude decir que son ni dos, ni tres ni cuatro sustancias diversas. $\mathrm{Y}$ esto mismo sucede en el caso de plantearse cosas buenas. Al poner los ejemplos de cosas buenas, san Agustín descubre que está indicando su propia duda y que su corazón está duramente dividido. La lectura de su sencillo argumento nos lleva a comprender la sincera tragedia que está sufriendo su interior; alma, corazón, entrañas, mente, en definitiva todo su ser: Hasta que no elija una opción seguirá el sufrimiento. Se le presenta a Aurelio Agustín un terrible dilema, como describe siendo ya un santo obispo, entre la "atractiva y agradable eternidad" deseada por la parte superior de su entidad, sin previa experiencia, y el acostumbrado deseo ya experimentado del bien temporal que le tiene encadenado. Se desgarra con gran dolor su alma al preferir aquello frente a la Verdad, puesto que el bien temporal le tiene atado $^{51}$.

Continúa con esa tortura del alma que siente como autoacusación. Se avergüenza ante Dios porque en su mente se le presenta la posibilidad de un mayor desfallecimiento. Todo esto le atormentaba y le producía un gran sufrimient ${ }^{52}$. Se reprocha no lograr romper las ligaduras que estaban menos ceñidas y más débiles, pero temía que se endurecieran más. Él interpreta que Dios con su severa misericordia le atormentaba por exigirle ya una respuesta sin reparos. Comprendía que era el momento de decidir y obrar, pero sin éxito alguno, que le coloca como al borde de un precipicio, pero sin caer al abismo del pasado. Repetía que debía decidirse ahora y pasar de la indecisión a obrar, y no llegaba aún a ponerse en obra. Tomaba aliento, y lo intentaba de nuevo, casi llegaba a conseguirlo. Dudaba en morir a la muerte y vivir a la vida, pero en él más podía el mal inveterado que lo bueno inusitado. Y se llenaba de horror presintiendo más cercano el momento de la decisión. Sabía ya que no iba a volver atrás ni apartarse del fin, pero algo le mantenía suspenso. Le daba horror señalar un dia, un ahora. "¿Crees tú -le decía la costumbre violentaque podrás vivir sin estas cosas? ${ }^{53}$

${ }^{51}$ Confesiones VIII, 10,24.

52 Utliza dos verbos profundamente significativos: aegrotabam y excruciabar (Confesiones VIII,11,25). Aegrotabam (del verbo aegroto, que significa muy débil con gran sufrimiento), y excruciabar. La palabra excruciatio -onis es un término creado y utilizado por san Agustín; es derivado de cruor-oris "derramando sangre" Cfr. ERNOUT, A.,-MEILLET, A., Dictionnaire étymologique de la langue latine, Paris 2001, VALBUENA-SALVÁ, Diccionario latinoespañol, Valencia 1850.

${ }^{53}$ Confesiones VIII, 11,25, 
Y “esas cosas” eran bagatelas ${ }^{54}$, llamadas por él "antiguas amigas" que le acosaban diciendo: “¿Ya no te permitirás gozar de esta cosas?”. Lo sentía ya menos de la mitad que antes, como si susurrasen a su espalda. Y repetían lo mismo: “Crees que vas a poder vivir sin estas cosas?”. Le sugerían con falacia que pensara en esto y aquello que nunca más se le permitiría. Y pleno de confianza, invoca a Dios "aléjalas del alma de tu siervo" 55 en una humilde reacción que abarca su pasado, como Aurelio Agustín, y su presente, como Obispo de Hipona. Esas sugerencias se iban haciendo cada vez menos incisivas y menos frecuentes, pero no cejaban aún en la lejanía, para que las atendiera, musitar que no podría vivir sin ellas ${ }^{56}$.

En el apartado anterior a la escena del jardín de Milán ${ }^{57}$, nos describe san Agustín cuál era concretamente el grado de perplejidad que sufrió entonces. Su importancia, entre otros aspectos, está en el siguiente párrafo: "Mas esto lo decía muy tibiamente, porque por aquella parte hacia donde yo tenía dirigido el rostro y a donde temía pasar, se me dejaba ver la casta dignidad de la continencia, serena y alegre, no disolutamente, acariciándome honestamente para que me acercase y no vacilara y extendiéndoseme hacia mi para recibirme y abrazarme sus piadosas manos llenas de multitud de buenos ejemplos, en niños, jóvenes, hombres de toda edad, viudas, vírgenes y ancianas y, en todas, una misma continencia, no estéril sino fecunda de hijos nacidos de los gozos de su esposo, tú, Oh Señor. “¿Por qué te apoyas en ti, que no puedes tenerte en pie? Arrójate en él, no temas que él te recibirá y sanará" "58. Es evidente que el tema de su indecisión radicaba en la dificultad para disponerse a aceptar el celibato, y entregarse al servicio de Dios. Mientras, siente la contienda de su corazón. Su conciencia le hablaba y le conminaba a decir a las tentaciones de la carne que sus delicias no pueden ser comparables a los deleites que son conformes a la Ley del Señor. Como resumen, dice: "tal era la contienda de mí mismo contra mi mismo". Mientras, Alipio, a su lado, aguardaba en silencio el desenlace de su inusitada emoción ${ }^{59}$

NOTA SECUNDARIA. Llegado a este punto nos preguntamos si santa Mónica tenía algún conocimiento del problema de su hijo. Ciertamente ella conocía algo de su trayectoria espiritual, pero no podía figurarse el alcance de su indecisión ni su desasosiego interior. Sabemos que pactó, en su calidad

\footnotetext{
${ }^{54} \mathrm{Su}$ frase, realista como hermosa, es: "Bagatelas de bagatelas y vanidad de vanidades" Confesiones VIII,11,26.

55 "Avertat ab anima servi tui misericordia tua", Confesiones VIII,11,26.

${ }^{56}$ Confesiones VIII, 11,26

${ }^{57}$ Confesiones VIII,11,27

${ }^{58}$ Confesiones, Ibídem.

${ }^{59}$ Confesiones, ibídem.
} 
de viuda materfamilias bereber con cierto matiz romano, una pretendiente para el matrimonio de su hijo ${ }^{60}$. Nos lo concreta san Agustín en otro momento anterior, cuando describe su llegada a Milán: "Conocía ella por san Ambrosio que había venido yo en aquel intermedio a dar en aquella fluctuante indecisión"61. Pero no hay argumento para deducir que supusiera que su hijo Aurelio Agustín tenía planteado el entregarse al servicio de Dios.

\subsection{La luz en el jardin de Milán: (Confesiones VIII,12,28-30)}

"¿Qué es lo que nos pasa, Alipio?"62 es la frase que emplea san Agustín al término de la visita de Ponticiano para comenzar un coloquio de corazones entre el de Alipio y el suyo. Son fieles corazones amigos. En la reflexión que desarrolla en este pasaje, a mi entender, intenta asimilar el por qué ellos, Alipio y él, con sus mentes selectas no han llegado a elegir y abrazar la forma de vivir que desde hace tiempo habían vislumbrado. "Al hacer un profundo examen extraje toda mi miseria de lo más recóndito de mi ser y la puse delante de la mirada de mi corazón lo que originó una enorme tormenta que contenía una copiosa lluvia de lágrimas" ${ }^{33}$. Esto le obliga a separarse de Alipio y busca la soledad y entre ellos se dicen frases ininteligibles. Mientras Alipio que respeta la intimidad de Aurelio Agustín, deja a su amigo que termine postrándose debajo de una higuera. El obispo de Hipona confiesa que en esa ocasión dijo muchas cosas parecidas a lo que escribe: "Y tú, Señor, hasta cuándo, Hasta cuándo has de estar irritado, No quieras más acordarte de nuestras iniquidades antiguas (Sal. 6,4 y 78,5). ¿hasta cuándo, hasta cuándo, imañana! ¡mañana!, ¿por qué no hoy, ¿por qué no poner fin a mis torpezas en esta misma hora? ${ }^{64}$.

Siente una amarguísima contrición de corazón que le hace llorar. En ese momento oye una voz infantil que repetía muchas veces "Déjalo ya, lee, déjalo ya, lee" ${ }^{95}$. Lo interpretó como un mandato divino, a semejanza de lo que san Antonio

${ }^{60}$ Confesiones VI,13,23.

${ }^{61}$ Confesiones VI, 1,1

${ }^{62}$ Confesiones VIII, 8,19,

${ }^{63} \mathrm{El}$ texto contiene las palabras latinas "alta consideratio" traducida en las ediciones de la BAC por "alta consideración". La palabra latina "consideratio" tiene su raíz en sidus-eris. Se usaba casi exclusivamente en plural y en su singular fue asumido por Virgilio y Horacio, que influyeron en san Agustín. Significa una constelación planetaria, opuesta a stella que es una estrella aislada Cfr. ERNOUT-MEILLET, o.c. Presento en el texto una traducción en español más asequible, en mi opiión, por considerar la frase latina fundamental y bella, al mismo tiempo.

${ }^{64}$ Confesiones VIII,12,28.

65 "Et ecce audio vocem de vicina domo, cum cantu dicentis et crebro repetentis quasi pueri et puellae nescio: «Tolle, lege, tolle, lege»” Confesiones VIII,12,29. La razón de esta traducción lo desarrollo más adelante. 
llevó a cabo, leyendo una página al azar del Nuevo Testamento para encontrar la fuerza que le faltaba. Volvió al lugar donde estuvo sentado, en el que había dejado el códice: y dice esta importante frase: Le arrebaté , lo abrí y lei en silencio lo primero que vieron mis ojos" $"$. Es decir. "No en comilonas y embriagueces, no en lechos y en liviandades, no en contiendas y emulaciones, sino revestios de nuestro señor Jesucristo y no cuidéis de la carne con demasiados deseos" (Rom $13,13)^{67}$. No quiso leer más ni era necesario, pues sus dudas se desvanecieron. Pero la última parte de la cita paulina es la que, en mi opinión, atrajo a Aurelio Agustín a ofrecerse profundamente al servicio de Dios.

Le indicó a san Alipio lo que había pasado por él, y éste a su vez lo que había experimentado y que san Agustín desconocía. Entonces pidió ver lo que yo había leído, y se lo mostró y atendió lo que seguía, que yo ignoraba, y que eran las siguientes palabras "Recibid al débil en la fe" (Roma 4,1) y que él se aplicó y me lo comunicó. Y dejando constancia de que Alipio le aventajaba en las costumbres, los dos fueron a comunicárselo a santa Mónica, hecho que dejó reflejado en una frase contundente: "Inde ad matrem ingredimur, indicamus, gaudet" (Entramos donde estaba mi madre, se lo indicamos, y se alegró",68.

NOTA ANALÍTICA: Precisa un sencillo análisis el siguiente texto agustiniano "El ecce audio vocem de vicina domo" del que resaltamos dos afirmaciones a tener en cuenta: -lo que oye es una voz, y esa voz proviene de una casa vecina ${ }^{69}$. Que la voz procediera de "una casa vecina" ayuda a dar una mayor fuerza a la hipótesis que más adelante presentamos respecto de que el "tolle, lege" se

\footnotetext{
66 “Arripui, aperui, et legi in silentio quo primum iniecti sunt oculi mei” Confesiones VIII,12,29.

67 "Non in comissationibus et ebrietatibus, non in cubilibus et impudicitiis, non in contentione et aemulatione, sed induite Dominum Jesum Christum et carnis providentiam ne feceritis in concupiscentiis" Confesiones VIII,12,29.

${ }^{68}$ Confesiones VIII, 12,30.

${ }^{69}$ Esa voz, que ciertamente indica el obispo de Hipona como histórica, quizás haya influido en otro famoso texto agustiniano, indebidamente, en mi opinión, para traducir "voz" donde no se hace referencia a palabras pronunciadas. En la traducción española de Soliloquios de la Editorial BAC, texto escrito en Casiciaco en el año 387, es decir, poco tiempo después de la Conversión de san Agustín en el Jardín de Milán, aparece la frase siguiente: "Volventi mihi multa ac varia ... quidve mali evitandum esset, ait mihi súbito sive ego ipse sive alius quis extrinsecus sive intrinsecus, nescio.... Ait ergo mihi"; Soliloquios I,1,1. En la tradución de la Ed. BAC, se dice: "Durante muchos años me consagraba... al bien que debo hacer y a los males que evitar, cuando de repente oí una voz interior, no sé si de mí mismo o de otro, que en lo íntimo o desde fuera me hablaba... Díjome, pues, aquella voz". Considero esta traducción un tanto equívoca, porque pudiera interpretarse por algunos autores contra la historicidad del pasaje de Confesiones. Cfr. San AGUSTÍN, Soliloquios, Obras de san Agustín, vol. 1º , Ed. BAC Madrid (2 ed.) 1950 p.498., La edición de la BAC del año 1994 (6 ed. p.435). En esta edición aparece un tanto variada, más clara, pero manteniendo las palabras "voz" "hablaba". El pasaje de Confesiones con su referencia a la voz, en mi opinión, debe ser respetado como histórico, porque, desde luego, San Agustín no da motivo para interpretarla de otra forma. Y la frase de Soliloquios no debiera interpretarse como sonido alguno.
} 
cantara por una voz infantil. Se precisa, además, una sencilla reflexión sobre el versículo leído por Aurelio Agustín, ya que la segunda parte del mismo es frecuentemente soslayada: “...sino revestios de nuestro señor Jesucristo y no cuidéis de la carne con demasiados deseos". El versículo es fundamental para juzgar el aspecto teológico de su conversión en la referencia al "revestirse de nuestro señor Jesucristo", es decir, a la conciencia personal que para él tuvo la importancia de Jesucristo en su vida. Ya anteriormente, cuando él tenía 18 años en Confesiones III,4,7 en la lectura del Hortensio que tantos bienes le produjo, sin embargo "una cosa me resfriaba tan gran incendio, y era el no ver allí escrito el nombre de Cristo, cuyo nombre él había bebido con la leche materna. Y también relata en Confesiones III,11,19-20, unos nueve años antes de la fecha de su conversión el diálogo con su madre por causa de una visión acerca de si sí o no estaría con ella en la regla (¿viga?) de madera" (la regla de la fe, o la Cruz). Cuando abandona a los maniqueos, asimila la duda que le causaron los académicos y lamenta no hallar en ellos el saludable nombre de Cristo, y entonces decidió ser catecúmeno de la Iglesia Católica que "mis padres me habían recomendado hasta tanto brillase algo cierto" (Confesiones V,14,25). Todo esto demuestra la diferencia entre la conversión de san Agustín y la de san Alipio, que ahora explicamos.

\subsection{La conversión de Alipio}

Todo lo anterior ha sido un extenso recorrido de reflexiones agustinianas, comentarios y sugerencias sobre el texto de Confesiones VIII, tan bello como conocido. En consonancia con la frase de Romanos "recibid al débil en la fe" (Rom 4,1) que Alipio se apropió, nos planteamos si existen diferencias entre la conversión de Agustín y la de Alipio. Hasta aquí hemos reflejado los aspectos más importantes que san Agustin nos narra acerca de su "conversión", y brevemente nos indica de semejante manera lo acontecido en la de su amigo más íntimo, san Alipio. Por cierto, se puede ampliar los datos normales sobre la conversión de san Alipio gracias al estudio del agustino holandés Hans van den Berg, con quien tuve hace años la grata oportunidad de realizar cierto trabajo intelectual. Van den Berg publicó en el año 2018 una muy conseguida biografía sobre san Alipio y añade una referencia extensa sobre escritos de diverso género que tienen como tema la figura del santo obispo de Tagaste ${ }^{70}$. Resumo esta publicación que empieza considerando la cita de Confesiones VIII,12,30 como el eje de especial atención para cuantos se han dedicado a exponer lo sucedido en la mente de san Alipio ${ }^{71}$.

\footnotetext{
${ }^{70}$ VAN DEN BERG, H., Alipio de Tagaste. Historia y Ficción, México 2018, pp. 675.

${ }^{71}$ VAN DEN BERG, H., o.c., pp. 63-73.
} 
El teólogo calvinista holandés J.H.van Haeringen (1887-1948) en 1921 viene a mostrar, tal como se desprende de Confesiones, que Alipio decidió vivir en continencia al querer formar una comunidad para buscar la Sabiduría que sería "una especie de huida del mundo de carácter filosófico sobre una base neutral" Como tesis inicial plantea que el proceso de conversión de Alipio se inicia y se culmina más tarde que el de Agustín. La primera diferencia con el proceso de Agustín se señala en la escena del jardín, pues su opinión es que Alipio no muestra la claridad de ideas de san Agustín respecto de la fe cristiana. Dice que es cierto que los dos son catecúmenos cuando se encontraban en la finca de Casiciaco, según leemos en Confesiones ${ }^{73}$. Dice san Agustín "en compañía de Alipio, también catecúmeno" ${ }^{\text {"74 }}$. Hubo de pasar un cierto tiempo hasta que éste conociera y creyera en la persona de "tu Unigénito Jesucristo, Señor y Salvador nuestro" 75 .

Desde 1921, año de la publicación del artículo de Haeringen, pasan años sin que apareciera ningún otro comentario hasta el que señalamos a continuación. Fue en 1968 cuando André Mandouze (1916-2006) ${ }^{76}$ ponderando la frase de Confesiones: "así era entonces este amigo tan íntimamente unido a mí, y que juntamente conmigo vacilaba sobre el modo de vida que habíamos de seguir"77 sugiere una personal interpretación. Se fundamenta esta interpetación sobre la frase siguiente: "Y fortificado con tal admonición y sin ninguna turbulenta vacilación, se abrazó con grata determinación y santo propósito", por lo que concluye que ambos compartieron la misma opción. Vencen los ideales ascéticos de Alipio sobre los mundanos de Agustín, y considera que Alipio no es simplemente seguidor de Agustín, contra la generalizada opinión de los agustinólogos que le consideran como realmente su sombra ${ }^{78}$.

Para Maurice Testard (1921-2006) ${ }^{79}$, la influencia de Alipio en Agustín es negativa y su intento para que le imitara un fracaso. Agustín se opone a la

${ }^{72}$ Sic en: VAN DEN BERG, H., o.c., p. 64.

${ }^{73}$ San Agustín ya era catecúmeno cuando él narra la escena del jardín, pues nos lo manifiesta abiertamente en Confesiones V,14,25,

${ }^{74}$ Confesiones IX, 4,8 .

${ }^{75}$ Confesiones IX,4,7.

${ }^{76}$ VAN DEN BERG, H, o.c. p. 65. Cita la obra de MANDOUZE, A., Saint Augustin, l'aventure de la raison et de la grace, Paris, Études Augustiniennes 1968.

${ }^{77}$ Confesiones VI,10,16,

${ }^{78}$ De la debilidad pasa a estar "firmatus", con agrado (placito), en la santa comunión de vida (propósito bono). Confesiones VIII, 12,30, Cfr. VAN DEN BERG, H., o.c., p. 65-67, cita a STARNES, C., Augustine's Conversion and the ninth book of the Confessions en Augustine: from rhetor to theologian, Waterloo 1992, pp.51-65. También es citado HOLTE, R., "Monica, the philosopher", en Augustinus, 39 (1999) 293-316.

79 TESTARD. M., “Observations sur la conversión d'Augustin et d'Alypius au jardín de Milan”, en Forschungen zur römischen Literatur. Festschrift zum 60. Geburststag von Karl Bücher, vol. 2., Wiesbaden, 1970, 266-273 
idea de Alipio, con el ejemplo de personas casadas que han ganado el favor de Dios y en efecto, es él quien convence y arrastra a su amigo ${ }^{80}$. Sus crisis son distintas. Para Testard, Agustín tenía vencida una crisis intelectual y en el jardín de Milán supera la crisis moral, mientras que Alipio tenía adquirido un ideal moral y con mayor dificultad llegó a una verdadera fe cristiana ${ }^{81}$.

Por último, Geert Van Reyn ${ }^{82}$, reduce el tema de la conversión de Alipio al modo que aplicó a sí mismo el versículo 4,1 de Romanos. Interpreta que es una carga sobre san Agustín el recibir y ayudarle en la fe, siguiendo la relación entre ellos de maestro y discípulo. En opinión de Carl Vaught ${ }^{83}$, Alipio se transforma de "infirmus in fide" a "firmatus in fide". El "placitoque ac proposito" lo entiende en cuanto acepta las exigencias del catecumenado en vias al bautismo, uno antes, Agustín, y Alipio un poco más tarde. Sencillamente, Agustin orienta a Alipio hacia el camino de Cristo que con este aspecto teológico perfecciona la anterior forma ética de vivir que éste ya tenía ${ }^{84}$.

Hasta aquí el resumen de la exposición que Hans van den Berg presenta en su libro sobre la conversión de san Alipio. Permítasenos aquí añadir nuestra propia interpretación sobre la conversión de san Alipio. El mismo san Agustín confiesa que Alipio le superaba en el tema de permaneer célibe ${ }^{85}$, pero Aurelio Agustín poseía ya una idea bastante más clara sobre la importancia de Cristo, de la que carecía Alipio, o, al menos, ignoramos si existe otra fuente que demuestre lo contrario. Por lo que la frase de Romano 4,1 afecta directamente a Alipio, quien se considera, en verdad, más débil respecto del conocimiento y especialmente sobre su confianza en Cristo. Ésta es la razón por la que el tiempo de su catecumenado no es el mismo que el de Aurelio Agustín. San Agustín nos narra que hacía tiempo que era catecúmeno. Lo dice expresamente al abandonar el maniqueísmo y estar afectado por causa de la doctrina de la duda académica: "determiné ser catecúmeno en la Igesia Católica que me había sido encomendada por mis padres" $"$. Es justicia resaltar en beneficio de Patricio que esta decisión es motivada por la recomendación de sus padres, no únicamente por su madre.

${ }^{80}$ Citado por VAN DEN BERG, H., o.c., pp. 67-68. Se basa en Confesiones VI,12, 19-22.

${ }^{81}$ VAN DEN BERG, H, o.c., p.69.

82 VAN REYN, G., "Ad christianam fidem pigrius movebatur (Conf. VII,20,25)" en, Augustiniana 59 / 3-4 (2009) 191-225; 60 / 3-4 (2010) 193-234

83 VAUGHT, C., Encounters with God in Augustine"s Confessions: books VII-IX, New York 2004, p. 100.

${ }^{84}$ VAN DEN BERG,H., o.c., pp. 71-73.

${ }^{85}$ Confesiones V, 14,25,

${ }^{86}$ Confesiones V,14,25. Hay que reconocer que san Agustín utiliza la palabra "statui" por la que no se concluye si efectivamente se presentó y sometió a la exigencia del Catecumenado. Véase también De utilitate credendi, VIII,20, incluso Soliloquios II,14,26, y Confesiones VI, 3, 3-5. 


\section{DOS TEMAS A DILUCIDAR}

Dos son los temas que deseamos dilucidar: El primero es el versículo de la Epístola a los Romanos 13,13 que relacionaremos con la dura experiencia de san Agustín, en Hipona. Siendo un sacerdote novel, se enfrenta a los excesos de sus fieles con motivo de la Fiesta de la Leticia. El segundo es el sentido que contiene la palabra "tolle" en la frase "tolle, lege, tolle,lege", cuyo significado, como ya hemos indicado es ¡Déjalo ya”, referido a las dificultades, tentaciones y especialmente su profunda y angustiosa indecisión para dedicarse al servicio de Dios.

\subsection{Romanos 13,13. MILÁN año 393}

Para entender y ahondar en la frase de Rom 13,13 que fue decisiva en su conversión nos planteamos qué relación tiene con este trascendental suceso, con otros en los que tiene también una gran influencia este mismo versículo paulino.

San Agustín en el año 393 ha de enfrentarse a los fieles de la Diócesis de Hipona ante los abusos que se cometían en la fiesta denominada "Laetitia" fiesta en honor de los mártires que eran muy venerados por los fieles ${ }^{88}$. Anteriormente en el año 392 envía una carta a Aurelio, obispo de Cartago con la principal idea de agradecerle que permitiera que Alipio, al que se pretendía ordenar sacerdote para esa diócesis, permaneciese en Hipona junto a él. Después de comentar las nefastas miserias morales que sufre la Iglesia de África, citando el versículo 13,13 de la carta de san Pablo a los Romanos argumenta con precisión y analiza toda su transcendencia. Explica que la Iglesia repudia y castiga los excesos cometidos "in cubilibus et impudicitiis" y transige y se muestra tolerante con los que el apóstol señala los primeros y los terceros ("in comessationibus et ebritatibus... in contentione et dolo"). Si la Iglesia considera crímenes los señalados en primer lugar ¿por qué no se califican igualmente crímenes los otros dos? ¿Por qué se consienten éstos dos últimos? En esta

${ }^{87}$ Laetitia significa alegría, y siendo una celebración cristiana tenía evidentes reminiscencias paganas. Algunos autores señalan que esta escena sucede en la Basílica Leonciana de Hipona. Esta opinión no parece tener fuerza alguna, pues las fuentes aluden que estaba presente el obispo Valerio, y la única Basílica con exedra para la presencia del obispo no podría ser otra que la Basilica Pacis. Cfr. VILLEGAS RODRÍGUEZ, M. Basílica de la Paz, sede episcopal de san Agustín, en Simposium XXVII - 2019, Instituto Escurialense de Investigaciones Históricas y Artísticas, San Lorenzo de El Escorial 2019.

${ }^{88}$ VILLEGAS RODRÍGUEZ, M., La devoción a los santos en los escritos de san Agustín, en Simposium 2-5/09/2008, Instituto Escurialense de Investigaciones Históricas y Artísticas, San Lorenzo de El Escorial 2008, pp. 7-21. 
carta, pues, aparece una de sus primeras citas bíblicas, que curiosamente coincide con la misma que él leyó en el jardín de Milán. Y afirma: "desterremos tanta vergüenza, al menos, de los sepulcros en que yacen cuerpos de los santos, pues en Roma ni en ninguna otra iglesia transmarina se permiten, y si alguna vez se introdujo, fue suprimida por el celo de ciertos obispos santos" ${ }^{\prime 9}$.

Un año después, en el año 393, el sacerdote Agustín, con anuencia del anciano obispo Valerio, asume la responsabilidad de suprimir de la diócesis de Hipona esta desviada costumbre de la fiesta de la "Laetitia", en la que, con la excusa de honrar a los mártires, los fieles hiponenses se dedicaban a comer y beber hasta llegar a degradante borrachera. La palabra del gran retórico está ya impregnada del espíritu del evangelio; enseña, amonesta, ama. La actitud de Agustín es muy difícil, pues él ya está tan impregnado del espíritu del Amor que para lograrlo necesita convencer a sus fieles. Quiere imponerse con dulzura y sin desánimo. Todo cuanto sucedió lo conocemos gracias a la carta que dirige a su gran amigo Alipio ${ }^{90}$, quien en ese momento era ya obispo de Tagaste. Por la primera (carta 22) se conoce el argumento y base teológica de la decisión de Agustín, y en la segunda (carta 29) cómo sucedieron los días y cómo fue complicada y dificil la situación para san Agustín ${ }^{91}$.

\subsubsection{Santa Mónica en Milán, año 385}

Conviene hacer una breve referencia a la situación embarazosa que desencadena santa Mónica al querer celebra en Milán lo que ella acostumbraba hacer en África. La primera noticia en relación con la fiesta de la Leticia en los escritos agustinianos y que contenga alguna coincidencia, está descrita por san Agustín a la llegada de su madre a Milán: "Ya había venido a mi lado la madre, fuerte por su piedad y segura de ti en todos los peligros ${ }^{, 92}$. Recordemos que, durante su navegación desde Cartago a Roma, intervino con fortaleza

89 “...saltem de sanctorum corporum sepulchris, de locis sacramentorum, de domibus orationum tantum dedecus arceatur" Epist. 22,3-4. Obras Completas de San Agustín, Ed. BAC, VIII, Madrid 1951, pp. 90-92.

${ }^{90}$ Se señala (Ed. BAC, Obras de san Agustín, vol.VIII, p.155) que esta carta está escrita en el año 395, pero se constata que los hechos suceden en abril del año 394, durante la cuaresma (cfr. Carta 29,3). Predicó un miércoles, antes de la cuaresma (Cfr.carta 29,2), El primer día de cuaresma predica otra vez con asistencia de muchos fieles fiels (cfr. Carta 29,3). El sermón se prolongó con numerosas citas de la Biblia y explicaciones concretas, en un momento álgido él confiesa que mostró su dolor llorando junto con muchos de los fieles (cfr. Carta 29,7).

${ }^{91}$ Cfr. VILLEGAS RODRÍGUEZ, M., "La devoción a los santos en los escritos de san Agustín" en Simposium 2-5/9/2008, Instituto de Investigaciones Históricas y Artísticas, San Lorenzo de El Escorial 2008, pp. 7-21.

${ }^{92}$ Confesiones VI,1,1. 
para animar a los marineros diciéndoles que llegarían a puerto seguro porque el Señor se lo había prometido en una visión ${ }^{93}$. Cuando santa Mónica llega a Milán, san Agustín había dejado de ser maniqueo, pero aún no era un cristiano católico. Mas ella serenamente aguardaba, como la viuda del evangelio, el momento para la resurrección de su hijo. No se equivocaba Mónica al decirle: "antes de salir de esta vida te veré católico fiel" $"$.

En cierta ocasión (primeros meses del año 385) santa Mónica acudió a las Memorias de los Mártires con un canastillo lleno de puches, pan y vino. Esta ofrenda la realizaba frecuentemente en África, y siguiendo su costumbre pretendió hacer lo mismo en Milán, Pero resultó que el Ostiario encargado por el obispo le prohibió la entrada para el fin que ella pretendía. Parece ser que ella no llevó muy bien esta prohibición, pues Agustín tuvo que consultarlo con Ambrosio ${ }^{95}$, que clarificada la razón por la que se había prohibido, se lo trasladó a su madre, quien por ser Ambrosio quien lo mandara, le fue a ella más fácil aceptarlo ${ }^{96}$. En este caso la ofrenda y la forma de ofrecerlo era prudente, morigerada e incluso devota, pero para evitar los excesos que llevaban a muchos a la borrachera se impuso la norma de prohibición absoluta de llevar ofrendas comestibles y vino a la Memoria de los Mártires.

\subsubsection{La fiesta de la Leticia. Hipona, año 393}

Los fieles de la Diócesis de Hipona tenían la costumbre de honrar a los mártires llevando, en la fecha de su conmemoración junto a sus Memorias, toda clase de viandas y vino, que consumían con exceso y terminaban por emborracharse. El planteamento de san Agustín es valiente y claro: "Aunque fuese África el primero entre todos los países en lanzarse a suprimir esa infamia, sería digno de imitación; pero ya que en la mayor parte de Italia y en casi todas las demás Iglesias transmarinas, en parte porque nunca se propagó, y en parte, porque tras surgir e incluso perdurar, fue suprimida y borrada por la diligencia y celo de los obispos que pensaban en la vida futura, ¿cómo podemos dudar en corregir esta nuestra costumbre tan inmoral ante el ejemplo de tantas otras iglesias?" ${ }^{97}$. No puede admitir esos excesos en las Memorias de los mártires: "Estas embriagueces y festines desenfrenados en los cementerios de los mártires los tiene el pueblo indocto y carnal, no

\footnotetext{
${ }^{93}$ Ibídem.

${ }^{94}$ Ibídem.

95 Este hecho es narrado por san Agustín también en dos de sus cartas: Epist. 36,14,32.

Epist.54,2,3. Y en su obra Contra Juliano 1,5,10.

${ }^{96}$ Confesiones VI,2,2,

${ }^{97}$ Carta 22,4.
} 
sólo como honores de los mártires, sino también como alivio para los muertos". $\mathrm{Y}$ con gran serenidad, pero con una firme decisión narra en su carta al obispo que "Hay que desterrarlo con espiritu de suavidad y mansedumbre... estos abusos no se atajan, a mi entender, con asperezas, rigores y modos imperiosos. Más bien que mandar, hay que enseñar; más que amenazar hay que amonestar" ${ }^{98}$. Esta forma de resolver el abuso de sus fieles es de una sabia actitud espiritual, que está en las antípodas de la asumida por la autoridad en otros sucesos históricos en la Historia de la Iglesia. Frente a la mansa amonestación, surgen protestas por parte de muchos fieles contra quien desea eliminar sus abusos, y esas protestas llegan a convertirse en serias amenazas. Escribe a san Alipio que: "Después de tu partida me anunciaron que ciertos individuos se habian soliviantado, protestando que no podian tolerar la supresión de esa solemnidad que ellos llaman laetitia. Tratan en vano de enmascarar el nombre de borrachera. Recordarás que ya anunciaban su protesta cuando tú estabas aqui presente".

Observando esta reacción, san Agustín interviene en varios momentos: a) Predicó un miércoles, antes de la cuaresma $(29,2)$, b) El primer día de cuaresma predica otra vez con asistencia de muchos fieles $(29,3)$, c) Otro días el sermón se prolongó con numerosas citas de la Biblia y explicaciones concretas, y en un momento álgido él muestra su dolor rompiendo a llorar, y lo mismo hacen los fieles $(29,7)^{99}$.

Las protestas de algunos fieles arrecíaron hasta tal extremo que san Agustín toma la decisión de abandonar Hipona: "Al amanecer el día siguiente, cuando ellos solían preparar sus fauces y estómagos, se me anunció que algunos, aun de los que habían asistido a la plática anterior, no cesaban de protestar". Tenía tal fuerza la costumbre pésima en ellos, que, dejándose gobernar por la voz de la misma, decían: "¿Por qué ahora? Los que antes no lo prohibieron, no dejaban por eso de ser cristianos".

Al escuchar tal protesta, san Agustín ya no sabía qué argumentos más fuertes utilizar para reducir tanta rebeldía. Estaba determinado, si mantenían su opinión, a leerles aquel pasaje del profeta Ezequiel: «Queda absuelto el centinela si reveló el peligro», y si aquellos a quienes lo anunció no quisieran evitarlo, yo sacudiré mis vestidos y me marcharé" 100

Dispuesto a cumplirlo redacta un sermón especial para comunicar a los fieles su voluntad de marcharse de Hipona. Algo providencial sucede cuando

\footnotetext{
${ }^{98}$ Carta $29,2$.

99 Define san Agustín las lágrimas como "sangre del corazón" (Nam lacrimae sanguis cordis est), Sermón 77/B, 6 .

${ }^{100}$ Carta 29,8.
} 
una hora antes de subir a la cátedra entraron a verle aquellos mismos a quienes había oído lamentarse de que esa antigua costumbre fuere desterrada. Les recibió con blandura y en pocas palabras cambió su pensamiento, llevándolo al recto camino. Cuando llegó el momento de ocupar la cátedra, omitió la lectura que traía preparada y que ya no le pareció necesaria, para disertar brevemente sobre otra cuestión, consignando que a los que preguntaban: «¿Por qué ahora?», nada se les podría contestar más breve y verdadero que esto: «iSiquiera ahora!». Arrecia la protesta y aluden incluso a que en Roma está permitido, pues se citaron ejemplos de embriagueces cotidianas en la basílica romana de san Pedro y en lugares que estaban muy lejos de la inspección del obispo. San Agustín defiende que en una ciudad tan grande como Roma había muchedumbre de mundanos, especialmente peregrinos que llegaban y eran tanto más audaces cuanto más ignorantes de la costumbre $^{101}$. Al ver que todos con un solo sentir manifestaban buena voluntad y repudiaban la mala costumbre, les exhoró a que asistiesen por la tarde a la lectura divina y a la salmodia, pues, añadió que sería placentero celebrar ese día con mayor pureza y sinceridad que los otros. De este modo parecería fácilmente quiénes del concurso presente querían seguir a la razón y quiénes al vientre. Terminada la lectura, dio fin al sermón ${ }^{102}$.

Durante la tarde de ese mismo día se llenó de fieles deseosos de oír el sermón: Estando presente el obispo, se alternó la lectura con la salmodia. Cuando pensaba que su intervención había terminado de modo feliz y el problema se había resuelto, el anciano obispo le obligó, contra su voluntad a dirigir la palabra que todos esperaban. La plática fue breve y elevó una fervorosa acción de gracias a Dios. Tranquilizado su corazón, dio por terminada la habitual función vespertina, y se retiró con el obispo ${ }^{103}$.

A los dos años escasos de este suceso, en 395, el presbítero Agustín fue consagrado por el obispo Valerio, su obispo auxiliar ${ }^{104}$.

Hemos resumido para entender mejor el problema planteado a este nuevo sacerdote Agustín, pero, en mi opinión, es extraordinariamente fascinante la lectura personal y directa de esta importante y ejemplar carta dirigida al entonces ya obispo de Tagaste, Alipio,

Este suceso, vidrioso y dramático para Agustín, con 39 años y totalmente consagrado al servicio de Dios, no es algo que pueda ser olvidado. Teniendo

\footnotetext{
${ }^{101}$ Carta 29,10.

102 Ibídem o.c.

${ }^{103}$ Carta 29,11 .

${ }^{104}$ Fue un acto sacramental peculiar, pues ambos ignoraban que estaba prohibido consagrar obispo durante la vida del obispo titular.
} 
en cuenta que en razón de la carta 22 , recordemos, escrita a finales del año 392 en la que señala muy luminosamente el argumento bíblico para intervenir con toda su caridad tratando de erradicar los excesos de sus fieles, y que en el año 393, habiendo referido una narración histórica detallada de lo sucedido en días concretos, e incluso confesando que hubiera abandonado Hipona si el pueblo no hubiese reaccionado, me pregunto si además de nuestro agradecimiento por la milagrosa mano de Dios que le conservó donde, dos años después sería obispo ¿puede olvidársele la experiencia vivida en estos sucesos cuando escribe Confesiones? El tema se presta a varias respuestas. Ante la imposibilidad de resolverlo por medio de algún escrito de san Agustín que lo señalara, podemos indicar alguna explicación.

Hay que comparar y, acaso relacionar, los sucesos de las siguientes fechas: la fecha del piadoso descuido por parte de santa Mónica en Milán en el año 385, la fecha de la conversión en el jardín de Milán en el año 386, cuando Agustín tenía 32 años, y el problema de los excesos de sus fieles en la fiesta de la Leticia prohibida por el ya sacerdote Agustín en el año 393, y alrededor del año 400 cuando escribe las Confesiones.

Una hipótesis: Pudiera ser, y nos tenemos que contentar con suposiciones, que en el año 386 Aurelio Agustín después de leer el versículo 13,13 de la epístola a los Romanos, y convencido ya para servir al Señor, tuvo continuamente en su mente y en su corazón ese versículo. Mi opinión es que lo aplicó, seguramente, a toda su vida, pero que en aquél momento se centraba, tal como hemos señalado anteriormente, no en tener que renunciar a una opción pecaminosa, sino a una noble y sacramental unión que concreta en las palabras "simples bagatelas", como es el matrimonio en contraposición a un exclusivo servicio de su vida a Dios. En el año 393 está dedicado ya plenamente al estudio de la Biblia, y, por eso, en el año 391, siendo sacerdote, solicita del obispo Valerio le conceda más tiempo para profundizar sus conocimientos de la Biblia y así poder aconsejar con la suficiente ciencia a cuantos se lo pidan ${ }^{105}$. Por eso se puede afirmar que el extenso comentario o exégesis de Rom 13,13 en la carta 22 dirigida al obispo Valerio es, seguramente el primer comentario bíblico de san Agustín. La razón que explica esto es que "su frase", me refiero a Rom 13,13 al ser causa de su conversión, pensó de inmediato la adaptación para así convertir también a sus fieles de Hipona en el año.393.

${ }^{105}$ En Contra Académicos, obra dedicada a Romaniano -año 386- ampliamente afirma el benéfico y suave perfume de la Arabia con la lectura de libros platónicos, la firme decisión de permanecer en la religión de sus padres y el estudiar a fondo los escritos de san Pablo leyéndolos "intenssime atque castissime". Contra Academicos II,3-6. Tiene relación con Confesiones VII,21,27. 
En Confesiones no se encuentra lugar que haga referencia a esta posibilidad, y se guarda un respetuoso silencio de sus actividades como sacerdote, pudiera ser por la sencilla razón de que su autobiografía termina con la fecha del fallecimiento de santa Mónica ${ }^{106}$.

Otra hipótesis puede basarse en que san Agustín teniendo muy hondamente en el interior de su corazón la frase bíblica que leyó en el jardín de Milán, ahondase en ella, la estudiara (Carta 21) y deseara que tuviera tanto éxito como el que se produjo en su alma, y que indirectamente se aplicara a sus fieles de Hipona para que superasen, como así fue en efecto, los acostumbrados excesos de llegar a emborracharse con la disculpa de honrar a los mártires en la fiesta de la Leticia.

Lo cierto es que el silencio que él mantiene sobre este tema causa cierta admiración, pero es imposible que, en el año 400, mientras escribe Confesiones hubiera olvidado lo que pasó pocos años antes, cuando era sacerdote de la diócesis de Hipona, pero no quiso referirse a ello. Acaso no quiso narrar públicamente la grave tensión que sufrió, puesto que las Confesiones fueron escritas para ser leídas, y solo quiso comunicarlo por carta privada a su amigo Alipio. Hay que suponer que gran parte de sus fieles fueron personas conocidas, actores vivos de aquel trágico suceso para san Agustín.

\subsection{Tolle, lege}

En primer lugar, deseo resaltar de nuevo la fidelidad de lo sucedido en el jardín de Milán. San Agustín al describir la escena considera que oyó verdaderamente esas palabras. No obstante, decido no extenderme en este tema, que considero no es el momento apropiado ni la finalidad de este artículo. Algún autor, por ejemplo Alfaric, niega la veracidad de las Confesiones ${ }^{107}$. Otros, entre ellos Courcelle, rechazan que "tolle, lege, tolle, lege" haya sido cantado por un niño real ${ }^{108}$. Estas dos conclusiones tal como están expuestas en sus respectivos escritos no contienen, en mi opinión, argumentos convincentes.

No tengo la menor duda que san Agustín es completamente veraz no solo al escribir las Confesiones, sino al redactar todas sus obras. No existen serios

\footnotetext{
${ }^{106}$ En esta carta nos narra sus lágrimas al ser ordenado sacerdote, que algunos interpretaron como si deseara ya el obispado. Cfr. Epist. 21,2. Recordamso sus duras críticas a sacerdotes que ignoran o adulteran el texto bíblico: Serm. 137.

${ }^{107}$ ALFARIC, P., L'evolution intellectuelle de S. Augustin, Paris 1918.

108 “...quoique la voix pas celle d'un enfant réel”: COURCELLE, P., Recherches sur les Confessions de saint Augutin, Paris 1950, p. 181. (Nueva edición en 1980).
} 
argumentos para juzgarle de jugar con la mentira. Pueden ser interpretados de diversas formas según el criterio del escritor, pues no hay manera de tener conciencia de una seguridad completa cuando se presentan las hipótesis, no podemos preguntárselo directamente al autor y recibir de él una convincente respuesta, sobre todo si muy probablemente nos contestara contradiciendo lo que cada uno cree haber entendido. Yo me atengo y comparto lo que él mismo decía al interpretar unas frases del Génesis y, ante otras opiniones distintas a la suya, indica que es imposible conocer la auténtica porque no es posible preguntárselo a Moisés ${ }^{109}$.

Por consiguiente, después de sopesar durante mucho tiempo el canto de "tolle, lege, tolle, lege" propongo como una hipótesis más la siguiente: Ante todo se supone que la casa en la que vive san Agustín en la ciudad de Milán no estaba aislada, sino que por estar dentro de la ciudad, estaba rodeada de otras domus, excepto la fachada del atrium que daría a una calle. Pienso que la presencia de san Agustín no pasa desapercibida ni por vecinos mayores ni por sus hijos, niños y niñas, pues llamaría la atención él, como profesor de Retórica, Alipio por su dedicación al Derecho, Nebridio en su propia actividad, y por no extenderme en el listado de más convivientes, su Madre Mónica que había llegado de África con un nutrido grupo familiar. Los niños han tenido que escuchar muchas veces de forma directa o indirecta, en su propia escuela y en sus propias casas, una llamada de personas mayores para que presten atentos (Tolle!: ¡Deja de distraerte!) y un mandato para estudiar (Lege!: ¡Estudia! ¡lee!). Siguiendo con la hipótesis: pueden haber oído los niños muchas veces las conversaciones de Agustín y sus amigos, y en ese día algún niño ha escuchado ruido y voces con el tono extraño de conversación de Agustín y Alipio en el jardín, ¿no pudiera ser que, en tono travieso de guasa para con los vecinos profesores, entonaran un estribillo verdaderamente pícaro con las palabras "tolle, lege" sin saber ellos la transcendencia que el Señor producía en sus voces? Es esto un poco ingenuo, pero bastante corriente en todas las sociedades, y también ¿por qué no? en la sociedad romana. Lo importante es lo que san Agustín entiende: "reprimiendo el ímpetu de las lágrimas, me levanté, interpretando esto como una orden divina" "110. Lo claro de todo este pasaje, hay que reconocerlo, es la idea de Agustín acerca de la procedencia divina del hecho ¿externo e histórico? ¿interior e histórico?

Y una suposición -gratuita pero posible- que se ha de tener en cuenta ¿No habría niños vecinos que les conocían y había oído a Agustín y a Alipio, y a

${ }^{109}$ San Agustín creía que fue Moisés el autor del libro sobre el que expone, entre otras opiniones, la suya propia. Cfr. Confesiones, XII,3,5.

${ }^{110}$ Confesiones VIII,12,29. 
sus propios profesores o pedagogos que estudiaran y leyeran que se dirigían a ellos son gran ánimo de educarles y dirían, acaso, tolle!, lege! (¡déjalo ya! ¡lee!)? .

\subsubsection{El significado de Tolle}

Me referí al inicio que desde hace tiempo analizaba la palabra tolle y sus derivados tollite, tolluntur, etc, que encontré en las obras de san Agustín. He de confesar que esto no me ha llevado a ninguna conclusión, porque, la palabra tolle y derivados encontradas en sus obras iban acompañados de un acusativo al que daban sentido de coger-tomar o de quitar-desaparecer,

Para fijar mejor mi intención en este artículo repito las frases neotestamentarias ya referidas con anterioridad que incluyen la palabra tolle: "tolle, tolle, crucifige eum" en la versión latina de La Vulgata ${ }^{111}$ que se traduce con la exclamación española ¡fuera, fuera! Otro pasaje: Cristo dice a quien desee imitarle "tolle crucem tuam et sequere me" la tradución suele ser "Toma tu cruz y sígueme",112. O en el pasaje del paralítico: "tibi dico, surge, tolle grabatum tuum, et vade in domum tuam" (A tí te digo, toma tu camilla, y vete a tu casa) ${ }^{113}$.

Consideremos brevemente este tema en las obras de san Agustín. Emplea el término tolle 118 veces aproximadamente, pero no he encontrado nunca esa palabra sin estar clarificado su sentido por un acusativo. Entre las muchas frases en las que san Agustín utiliza el verbo tolle con el significado de "quita" cito dos ejemplos muy representativos y conocidos: la famosa frase del sermón 229,3 en donde se lee: "Tolle ergo verbum, panis est et vinum, adde verbum et fiet sacramentum" 114 , e igualmente la archiconocida en el Tratado sobre san Juan 15,43: "tolle aquam, non est baptismus: tolle verbum, non est baptismus" 115 . Sin duda, hay otras frases en las que el significado de tolle es tomar o coger. Pero el problema, se objetará siempre, es su signifcado en la frase de Confesiones.

Pasemos a algunas consideraciones que, en mi opinión, conducen a probar que tolle, lege en Confesiones significa ;déjalo!, por referirse a que Aurelio Agustín abandonara la dura indecisión y profunda crisis psicológico-moral que sufrió, narrada en Confesiones VIII, y que hemos querido resaltar en el presente artículo. Si no fuera así, entonces solo recibiría la orden de leer,

\footnotetext{
111 "Fuera, fuera, crucificale", Jn.19,15.

112 Mt. 16,24.

${ }_{113}$ Mc. 2,11,

114 "Quita la palabra y sólo hay pan y vino. Añade la palabra y es un sacramento".

115 "Quita el agua, no hay bautismo. Quita la palabra, no hay bautismo".
} 
estudiar, que, por cierto, ya estaba dedicado a ello. y quedaría sin respuesta o solución a su profunda duda vital.

1.- Ciertamente no hay en el original la conjunción copulativa -y-. San Agustín no escribió $\underline{e t}$, y por tanto, hay que comprender la frase con dos verbos en imperativo.

2.- En una frase con dos imperativos separados por una coma, cada uno encierra normalmente un mandato propio.

3.- La palabra tolle en el sentido de "tomar el códice" necesita un acusativo que señale el objeto que hay que tomar. No existe en la frase acusativo alguno.

4.- Es ilógico señalar a alguien que tome algo si no se ofrece. Es decir, quien dice "toma", normalmente, ha de ofrecer algo suyo.

5.- Es ilógico decir toma (referido a un códice) porque para leerse (lege) previamente hay que cogerlo.

6.- "Tolle" y "lege" no deben entenderse en sentido estático y concreto, porque la conversión es dinámica, no es un acto milagroso, sino una gracia continuada y segura.

7.- Si la conversión es decidir o asumir un camino, no tiene valor alguno el elegirlo, sino se ejerce un movimiento continuado, es decir dinámico.

8.- No se resuelve nada por leer Rom 13,13 sino se refiere a una continuación progresiva en la ciencia bíblica. (Además, san Agustín ya entonces, como he señalado en este artículo, tenía un suficiente conocimiento de las cartas de san Pablo).

9.- El considerar tolle, lege como una acción divina que convierte a Aurelio Agustín en un instante milagroso, no tiene valor si no hay una progresiva superación.

10.- La palabra tolle se refiere a quitar toda indecisión y toda duda que angustiosamente le ataba a Aurelio Agustín a esas bagatelas de bagatelas, vanidades de vanidades.

Pudiérase aumentar el listado de razones, pero termino ya, el tema planteado con la cita curiosa de san Isidoro de Sevilla, quien afirma indirectamente que tolle, lege significa evitar, quitar o soslayar las cosas perjudiciales y elegir todo lo que tiene un valor trascendental. Dice:

Sunt hic plura sacra, sunt hic mundalia plura;

ex his si qua placent carmina "tolle, lege",

prata vides plena spinis et copia floris;

si non vis spinas sumere, sume rosas ${ }^{116}$.

116 "Existen muchas cosas sagradas, y muchas mundanas / para elegirlas ten en cuenta la canción tolle, lege. /Ves en las praderas muchas espinas y cantidad de flores/ si no quieres las espinas, elige las flores" (PL 83,1107). 


\section{BIBLIOGRAFÍA}

- ALFARIC, P., L'évolution intellectuelle de S, Augustine, Paris 1918

- ALONSO DEL CAMPO, U., "La conversión del corazón. Valoración analítica de la experiencia de San Agustín en el jardín de Milán", en Angelicum, 48 (1971)139-170.

- ALONSO DEL CAMPO, U., Proceso psicológico de la conversión de San Agustín, Roma 1972, 79 pp.

- ALONSO DEL CAMPO, U. "La conversión de san Agustín. Validez de las fuentes psicobiográficas”, en Augustinus, 19 (1974) 127-143.

- BELINCHÖN, M.; TODA, J.M., y RIVIÈRE, A., Psicología del lenguaje, Investigación teórica, Ed.Trota, 2 ${ }^{\mathrm{a}}$ ed. Madrid 1994.

- FERRARI, L.C., "La escena de la conversión de san Agustín ¿El fin de un debate moderno?", en Augustinus, 36 (1991) 89-106.

- KATO, T., "Tolle, lege, Conf. 8,12,29, La voz de la narración y su realidad", en Augustinus, 40 (1995) 151-158.

- OROZ RETA, J., “Conversión”, en Diccionario de san Agustín, Burgos 2001

- STARNES, C., "La conversión de San Agustín y la lógica del libro VIII de las Confesiones", Augustinus 26 (1981) 247-252.

- VEGA, M. de la, Introducción a la Psicología cognitiva, Ed. AlianzaPsicología, $7^{a}$ reimpresión, Madrid 1994.

- VILLEGAS RODRÍGUEZ, M., "La devoción a los santos en los escritos de san Agustín", en Simposium 2008, Instituto Escurialense de Investigaciones Históricas y Artísticas, San Lorenzo de El Escorial 2008, pp. 7-21.

- VILLEGAS RODRÍGUEZ, M., "Tradiciones sobre los difuntos en San Agustín", en Simposium 2014, Instituto Escurialense de Investigaciones Históricas y Artísticas, San Lorenzo de El Escorial 2014, pp.23-30.

- VILlEGAS RODRÍGUEZ, M., "Basílica de la Paz, sede episcopal de san Agustín", en Simposium 2019, Instituto Escurialense de Investigaciones Históricas y Artísticas, San Lorenzo de El Escorial 2019. 